\title{
Beginnings of the Józef Piłsudski Institute in New York (1943-1956)
}

Summary: Józef Piłsudski Institute was founded in New York, July 4, 1943. The main aim was to maintain constant and independent scientific research facility dealing not only with collecting and organizing historical documents, but also with popularizing unadulterated knowledge about Poland and its recent history. From its earliest days the Institute was based on financial support granted by Polish activists and on membership fees, as well as on larger donations from some members. Since the late forties, when KNAPP activity slowly began to fade, actions and statements of people associated with the Institute were regarded as guidelines for independence environments. These people formed very cohesive environment, being faithful to Piłsudski heritage, negated any compromises with regard to Polish independence. It was strongly anticommunist rejecting all contacts with PRL institutions.

Thanks to the energetic work of people connected with the facility rapidly grew both archival and library collections. In 1949 the collection in the library had grown to 2500 books, periodicals reached up to 800 titles. To the library came valuable Polish diplomatic archives, collections of different personalities, as well as documents showing the huge effort of organizations of Poles, who after the end of the war were on the territory of West Germany.

Keywords: Józef Piłsudski Institute in New York, KNAPP, National Committee of Americans of Polish Descent

\section{Part I (1943-1950)}

The first plans connected with organizing the Józef Piłsudski Institute in the United States of America dated back to 1942. At that time Wacław Jędrzejewicz, Henryk Floyar-Rajchman and Ignacy Matuszewski took the initial steps to create - on the basis of the existing organizations of pro-independence orientation - a more significant movement including bigger centres of life of the Polish Community. The Committee for National Defence (for short in Polish KON) and the Alliance for 
National Defence named after Józef Piłsudski (for short in Polish ZON) served as its bases. ${ }^{1}$ Work was conducted on organizing a constitutional convention of the new organization, which at the beginning was supposed to be named the American Committee of Defense of Polish Rights (for short in Polish AKOPP). ${ }^{2}$ It was supposed to take place in the second half of June 1942 in New York. At that time its organizers intended to appoint the Institute. Information concerning this Institute is in ZON bulletin no. 5, where one can read: "lately on the territory of the Polish Community in America, there was an initiative in setting up a scientific institution, which would continue the activity of the Józef Piłsudski Institute, brutally disrupted by the force of an invader. This institution by collecting and drawing up materials on the territory of America, concerning both a political organization activity from the previous years of the war and current documents, which could partially, fulfil a gap in the scientific work on research on contemporary history of Poland. This initiative is right, vital, and healthy. It should find much support from the side of the Polish Community." 3 Additional information can be found in a hand written note - a resolution of Wacław Jędrzejewicz's authorship, in which he declared among others: "The AKOPP Convention states that the disruption and destruction, by Germans, of the work achievement of the Józef Piłsudski Institute, the study of contemporary history of Poland, is a huge loss for Polish culture. For that reason, the Convention calls upon the Main Board to take steps to set up, on the free territory of the United States, a scientific institution devoted to collecting materials. [...] On the basis of article 4 p. B and 5 of the AKOPP Constitution 'the Józef Piłsudski Institute...' is set up. This Institute has to be an independent legal institution having its statute. The tasks of the Institute will include conducting any works provided under article 4 p. B and 5 of the AKOPP Constitution (Documentation Department). The Main Board of the AKOPP will appoint the first ten members of the Institute."

However, those plans failed and the Institute was officially set up in New York a year later during the second convention of the KNAPP. Preparing for this fact, W. Jędrzejewicz informed activists known to him about correspondence addressed to them before the convention. Such a note can be found in a letter to Wackaw Gawroński living in Chicago, in which he stated among others: "Apart from that, a project of setting up a new institution in the form of an Institute for Research in the Contemporary History of Poland named after Józef Piłsudski, in which we could already act directly, not being moved aside every time, is on the agenda for us. It does not have anything in common with the National Committee but we have to

1 Archives of the Józef Piłsudski Institute in New York, archive by subject (later: ARz), zesp. 114, sygn. 340, News Bulletin of the Alliance for National Defense named after Józef Piłsudski and the Committee for National Defence, no. 5, May 11th 1942.

2 In reality during the convention, which took place on June 20th and 21st 1942 in New York, it was decided to accept the name of the National Committee of Americans of Polish Descent (KNAPP).

3 ibid., pp. 7, 8 .

$4 \mathrm{ARz}$ in the Józef Piłsudski Institute [for short JPI], NY, zesp. 114, sygn. 340, a hand written note of Wacław Jędrzejewicz containing 5 unnumbered pages. 
talk it over and discuss it. You are really needed for this. Therefore, we would like to see you here for a couple of days and before the convention [...]." Additional information can be found in material appended to the minutes on June 5th 1943, in which a note was included - a report signed by J. Piech, titled "The thought in New York took real shapes in Chicago." It was stated there that the decision to set up the Institute had previously been discussed in New York in a team consisting of I. Matuszewski, H. Floyar-Rajchman and W. Jedrzejewicz. On June 24th I. Matuszewski stayed in Chicago and on behalf of $13 \mathrm{KNAPP}$ he delivered a series of lectures there. At that time, during a private conversation with J. Piech and L.A. Kupferwasser, he presented the need to establish an Institute. Both Matuszewski's interlocutors agreed with his reasoning. ${ }^{6}$

The KNAPP Convention took place on June 3rd-4th 1943 in New York in rented rooms of the Washington Hotel at Lexington Avenue between 23rd and 24th street. The organizational meeting of the Institute was held, however, in the morning on June 4th 1943, at a distance of several streets, in the National House located at 19-24 Saint Mark's Place in Manhattan, New York. ${ }^{7}$ Józef Piech from Chicago was appointed the chairman of this meeting, and Witold Skubikowski was appointed as the secretary. Wacław Jędrzejewicz presented the intentions and work plan of the proposed institution, and at the request of Lucjusz A. Kupferwasser a branch of the Józef Piłsudski Institute of America was officially organised. The branch was supposed to continue the activity of the Institute in Warsaw which had been plundered by the Germans. The motion of H. Floyar-Rajchman was also accepted that the name of the Institute could not differ from the original one, which was used in Warsaw. In the resolution that was adopted, it was stressed that - on the territory of occupied Poland there were no possibilities of carrying on the statutory activity of the Institute - gathering and preparing materials concerning modern Polish history, so it had to be continued in conditions of war. For these purposes, according to the assembled, the territory of the United States was all the more suitable because in one place there were three members - founders of the Institute in Warsaw. It was decided to determine the Organizing Committee consisting of eight people with the right to co-opt members, and the aim of the Committee would be to organise and at the same time lead the Institute. It was also decided to continue after the war the activity of the Institute in New York as an American institution of the central office in Warsaw, which - as it was then thought - soon after the end of the war would be revived in its original shape in Warsaw. Then Franciszek Januszewski from Detroit was chosen as the chairman of the Organizing Committee of the Institute, his deputy was Ignacy Matuszewski, the secretary Marta Kozłowska was from Leonia, a small

5 Personal Archives [for short in Polish AOS] in the Józef Piłsudski Institute, NY, Wacław Gawroński’s file, W. Jędrzejewicz's letter to W. Gawroński, New York, June 9th 1943.

6 Archives of the Józef Piłsudski Institute in NY, J. Piech's note included in materials to the minutes on June 5th 1943.

7 Archives of the Józef Piłsudski Institute in NY, minutes of the organizational meeting of the Józef Piłsudski Institute of America. 
town in New Jersey, and J. Piech was the treasurer. Maksymilian Węgrzynek from New York, H. Floyar-Rajchman, L.A. Kupferwasser and Jan Zygmunt Dodatko from Detroit were members of the Committee. However, in an official version of an announcement on the creation of the Institute, it was decided to state that it was set up during the Convention of the National Committee in Washington Hotel. This was undoubtedly related to the wish to stress that the new archival and scientific institution was closely related to the idea of independence as associated with George Washington. It was also supposed to benefit from the support of people working in its ranks as well as its leadership that was to feel jointly responsible for the development of a new archival and scientific institution. ${ }^{8}$

Another day (July 5th 1943) at 3 p.m. in an editorial office of "Nowy Świat", lent by Maksymilian F. Węgrzynek, a session of the Organizing Committee took place. People who were at the same time delegates to the KANPP Convention took part in the session: Ignacy Matuszewski, W. Jędrzejewicz, L.A. Kupferwasser, L. Kozłowski, Nowiński, Zygmunt J. Słuszka, Edward Nowicki, Józef Piech, Marta Kozłowska, Stanisława Nowińska, Franciszek Januszewski, H. Floyar-Rajchman, Rosalak, Urbański, J. Z. Dodatko, Sylwester Sznura, Maksymilian Węgrzynek, Walter Cytacki, Stefan Łodzieski, and Witold Skubikowski. At the very beginning W. Skubikowski presented a paper "On setting up the American branch of the Józef Piłsudski Institute devoted to research on the contemporary history of Poland." Skubikowski said among others: "Following the words which were said by Wacław Sieroszewski that Piłsudski gave Liberty, Boundaries, Power, and Respect to Poland, we, Poles on the territory of the United States of North America, in particular, delegates of the KNAPP Convention gathered in New York, should take the initiative to establish a historical and scientific institution to celebrate the works of the Grand Marshal [also known as the First Marshal of Poland] in order to replace existing before the war the Józef Piłsudski Institute in Warsaw, and devoted to research into the contemporary history of Poland." In the next part the speaker stressed that the Institute before the war had been dealing with gathering documents concerning the activity of the Polish Socialist Party [in Polish: Polska Partia Socjalistyczna], the Rifle Association, the Legions, the Polish Military Organization [for short the PMO, in Polish Polska Organizacja Wojskowa, POW] and the interwar period in Poland. The Institute in the previous form: "damaged, robbed and closed by the Germans is not able to conduct research and gather documents of Marshal Piłsudski’s epoch and recent times. The Institute used to issue a quarterly 'Independence' conducted its research, employed many scholars researching the contemporary history of Poland. Nowadays, giving expression to understanding the need for continuing the work of the Józef Piłsudski Institute, we, Americans of Polish origin, together with refugees from Poland in the persons of I. Matuszewski, W. Jędrzejewicz, and H. Floyar-Rajchman, can continue the work of the Institute for the sake of future generations and Poland."

8 "A historical outline 1943", New York 1943, an anniversary bulletin issued by the Józef Piłsudski Institute (without the author of the text) that is commonly regarded as the work of W. Jęrrzejewicz. 
Next, Wacław Jędrzejewicz tabled a motion, in which he reminded those present that the previous chairmen of the Institute in Warsaw were: Walery Sławek and Aleksander Prystor. Those present in the room took this into consideration and they also agreed that the KNAPP Documentation Department would permanently cooperate with the Józef Piłsudski Institute. Another motion, tabled by L.A. Kupferwasser's, on "gathering materials concerning the present war by the Institute" was accepted.

H. Floyar-Rajchman defined the tasks which the newly created Józef Piłsudski Institute faced. He stated that: "The search for and defence of historical truths will be the aim of the Institute. So far Polish generations are born and they die not knowing historical truths and, throughout their lives in such conditions, they are not aware of their aims."

The chairman of the KNAPP, M. F. Węgrzynek offered the Institute, while it was organizing itself, one room in the office of the National Committee located in Charity Building no. 105 East at 22 street (room number 413). At the request of J. Piech, W. Jędrzejewicz was appointed its director who took the election with the proviso that, for some time, he would not be able to leave his current place of work in a factory. It was decided to inform Aleksandra Piłsudska, who was living in London, General Kazimierz Sosnkowski, Janusz Jędrzejewicz from Palestine "and all members of the Institute in Warsaw who could be found", about setting up the institution. The meeting ended with singing the Rota of Maria Konopnicka.

Indeed, notifications were sent to the mentioned people, but the response came with some delay because of communication problems during the war. Kazimierz Sosnkowski, the Commander-in-Chief, sent a letter, in which he acknowledged the news and he also informed about the kind response of Aleksandra Piłsudska; he stressed that he referred with joy to the information about setting up the Institute: "I send you wishes of fruitful work and greetings to old comrades-in-arms." 10

The second organizational meeting of the Committee took place on July 6th 1943. F. Januszewski, I. Matuszewski, J. Piech, M. Kozłowska, M. Węgrzynek, H. Floyar-Rajchman, W. Jedrzejewicz, W. Skubikowski, J.Z. Dodatko, and L.A. Kupferwasser were present there. The meeting was conducted by F. Januszewski, who was appointed chairman of the Institute by the assembled. His deputy was I. Matuszewski, the treasurer - J. Piech, the secretary - M. Kozłowska, and the director of the Institute - W. Jędrzejewicz. The above mentioned board was elected for 6 months and its aim was to organise an archival

9 A paper presented after the KNAPP Convention by W. Skubikowski dated July 5th 1943 concerning setting up the branch of the Józef Piłsudski Institute devoted to the study of recent Polish history, material to the minutes.

10 Report on the activity of the Institute since the establishment (July 4th 1943 to December 31st 1943), New York, 1944, p. 7. Minutes of the meeting of the Organizing Committee held on July 5th 1943, p. 2; AOG the Józef Piłsudski Institute, New York, General K. Sosnkowski, W. Jędrzejewicz’s letter to General K. Sosnkowski, New York, October 1st 1943, zesp. 93, volume 14/1; ibid., General K. Sosnkowski's letter, London January 11st 1944, L.dz. 43/44, vol. 14/2. 
and scientific institution definitely. It was enacted that an annual membership fee of the Institute would be 100 dollars. Previous decisions concerning the remuneration for a manager of the Institute in the amount of 200 dollars per month were confirmed and all documents were to be sent to W. Jędrzejewicz's home address (619 West 113 Street NYC). ${ }^{11}$

W. Jędrzejewicz spoke of the backstage personal decisions while organizing the Institute in his letter to Wacław Gawroński, in which he also informed about the convention of the Organizing Committee. He stated in the letter that - because M. Węgrzynek was appointed chairman of the KNAPP - they decided (i.e. undoubtedly Matuszewski, Rajman, Januszewski) "for the sake of fairness" to appoint Januszewski as the chairman. "At first we thought about Piech, I even talked with him about that, then however it turned out to be different. I have to stress the extraordinary loyalty of Piech who immediately agreed to give way to Januszewski. [...] Hence, we have new workspace thanks to which we will be co-hosts. Matuszewski is the vice-chairman so there will be real work. And I will help him as much as I can."12

However, those efforts failed because on July 6th 1943 F. Januszewski resigned in writing from his post. ${ }^{13}$ More information on the reasons of Januszewski's resignation can be found in his next letter to I. Matuszewski, in which he suggested that he did not accept the members of the Committee which was supposed to organize the Institute. He stated among others that: "Gentlemen, you would not change the determined composition of the Committee, however, I cannot undertake the leadership of the Committee composed, so it is difficult to think about my decision." 14 The resignation from the leadership of the Organizing Committee was also mentioned by W. Jędrzejewicz in correspondence addressed to J.Z. Dodatko in which he stressed that they could not understand his decision. He stated at that time that: "I do not know if he dreamt that he would be the chairman of a scientific institution connected with the name of J. Piłsudski. We do not have such a habit that on the second day after the election you renounce your post. [...] All the more so because just after the establishment of the Institute the three of us, together with Minister Matuszewski, spent a few hours speaking about the Institute and Januszewski expressed the greatest interest in the institution and apart from a lack of time and distance he did not have any reservations." 15

Other attempts in order to change Januszewski's decision (including a personal conversation conducted in the first half of September 1943 by I. Matuszewski in

11 Archives of the Józef Piłsudski Institute in NY, minutes of the second organizational meeting of the Józef Piłsudski Institute in New York which took place in an office called "Nowy Świat", July 6th 1943.

12 AOS in the Józef Piłsudski Institute, NY, Wacław Gawroński’s file, W. Jędrzejewicz’s letter to Wacław Gawroński, New York, July 5th 1943.

13 AOS in the Józef Piłsudski Institute, NY, F. Januszewski’s file, F. Januszewski’s letter to I. Matuszewski, Detroit (Michigan), July 6th 1943.

14 ibid., F. Januszewski’s letter to I. Matuszewski, Detroit (Michigan), August 26th 1943.

15 AOS in the Józef Piłsudski Institute, NY, J. Z. Dodatko’s file, W. Jędrzejewicz’s letter to J.Z. Dodatko, New York, August 9th 1943. 
Detroit) did not bring positive results and ultimately his request for resignation was examined on September 16th 1943 at the meeting of the Organizing Committee. I. Matuszewski, M. Kozłowska, H. Floyar-Rajchman, M. Węgrzynek and W. Jędrzejewicz were present at that time. The above mentioned resignation was accepted and at the same time it was decided not to choose a new chairman. Matuszewski at that time only formally acted as the chairman of the Institute until a General Meeting of members was held and the new authorities of the institute were elected. ${ }^{16}$ However, contacts with Januszewski did not cease at this point. We can find them in other correspondence where $\mathrm{W}$. Jędrzejewicz, raising the delicate matter of the decision of the chairman, who did not resign from membership of the institute, was to be asked by J.Z. Dodatko, as a member of the committee, about his membership fee. ${ }^{17}$ As a result of actions taken by J.Z. Dodatko we know that there was a conversation with Januszewski, who spoke favourably about the Institute and its leaders. ${ }^{18}$

During the meeting of the Organizing Committee on September 16th 1943 apart from accepting the official resignation of F. Januszewski, the Leader of the Organizing Committee, and entrusting this function to Ignacy Matuszewski, the final name of the Institute - the Józef Piłsudski Institute of America for Research in the Contemporary History of Poland [Amerykański Instytut Józefa Piłsudskiego Poświęcony Badaniu Najnowszej Historii Polski] was also determined. A current account in the bank of Manufacturers Trust Company, New York, was opened. I. Matuszewski, M. Kozłowska and W. Jędrzejewicz were entitled to sign cheques with the restriction that each cheque had to be signed by two of them. ${ }^{19}$

$\mathrm{W}$. Jędrzejewicz realised that he would be saddled with the lion's share of the effort in organizing the work and the office of the new institute, as well as encouraging people to support it financially. And that could take place after resigning from his job at Woynicz's factory, as eventually occurred in mid-September. Firstly, he organised an office in one of the KNAPP rooms (103 East 22 Street, room 413) granted by M.F. Węgrzynek. This gave the Institute at least temporary respite from standard running - rent, telephone and office equipment. Only one cabinet for records and files was purchased. At the very beginning, the staff of the Institute consisted of a director and a secretary, Pauline C. Ramsey, who was responsible for the creation of a library and cataloguing. ${ }^{20}$ In addition, Halina Matuszewska helped voluntarily.

16 AOS in the Józef Piłsudski Institute, NY, Franciszek Januszewski’s file, I. Matuszewski’s letter to F. Januszewski, New York, September 24th 1943; also in AOS in the Józef Piłsudski Institute, NY, J.Z. Dodatko's file, W. Jędrzejewicz's letter to J.Z. Dodatko, New York, September 24th 1943; also minutes of the meeting of the Organizing Committee of the Józef Piłsudski Institute on September 16th 1943.

17 ibid.

18 AOS in the Józef Piłsudski Institute, NY, J.Z. Dodatko's letter to W. Jędrzejewicz, Detroit, October 23th 1943.

19 The meeting took place in the private flat of Ignacy Matuszewski at 70 Riverside Drive, Manhattan in New York.

20 Report on the activity of the Institute since the establishment (July 4th 1943) till December 31st 1943, 1944, p. 6. 
Having organised the office, the founder members of the Institute directed their efforts to recruiting new members, mainly from among those who were present at the organizational meeting of the Institute. At the beginning there were many applications, usually, as the director defined, from refugees who were well off. However, it was not possible to collect fees in W. Jędrzejewicz's name and it was necessary to open a bank account for the Institute.

In order to develop an information campaign about the creation and activities of the Institute it was planned to take advantage of W. Jędrzejewicz's forthcoming autumn tour of the larger centres of Polish communities, including primarily those in Chicago, Milwakuee and Gary. It was supposed to be connected with a lecture presentation dedicated to Józef Piłsudski. Jędrzejewicz wrote about this to W. Gawroński: "I would stay longer in Chicago, many days to work in the Chicago library [...] I leave this initiative largely to you, my dear Consul, because I know that you will choose the right time for this and prepare with our friends everything what is needed. Anyway I expressed my readiness for this trip. Matuszewski suggested the same in Detroit and there they work on this." ${ }^{21}$ Jędrzejewicz, writing to Henryk Kogut living in Detroit, suggested that he will take part in meetings organised in cities and indicated to him by the hosts. However, he stressed that he would like to combine historical lectures devoted to Marshal Piłsudski "with the current political situation."22

In another letter, he stressed that he would like to find at least 35 members in Chicago and in its vicinity. In correspondence with Stefan Łodzieński, living in Lakewood (Ohio), Jędrzejewicz wrote that at the beginning of November he planned to go on a tour and he wanted to talk with many people personally about the Institute. The route passed through Cleveland (Ohio) where he was supposed to stay for two or three days and he intended to find there "at least 10 members of the Institute because he thought that the good example of Mrs. Siemiradzka should move others (in October she gave 1000 dollars to the Institute). I would be very grateful to the chairman for assisting in this work by searching out people who I could talk to."23

Jędrzejewicz wrote to J.Z. Dodatko in a similar way. He stated that in terms of the Institute he would like to find at least 30 members in Detroit and its vicinity. "That would be perfect and we have to do everything in order to succeed. Thank you for sending me a list of candidates with surnames and addresses, I shall write to them separately. I will send this list to you and ask you to collect them together. Or, if necessary, I can go to each of them and talk to them individually. I think that this will take six days." 24

21 AOS in the Józef Piłsudski Institute, NY, Wacław Gawroński’s file, W. Jędrzejewicz’s letter to W. Gawroński, New York, September 19th 1943.

22 AOS in the Józef Piłsudski Institute, NY, Henryk Kogut's file, W. Jędrzejewicz's letter to H. Kogut, New York, September 24th 1943.

23 AOS in the Józef Piłsudski Institute, NY, Stefan Łodzieński's file, W. Jędrzejewicz’s letter to S. Łodzieński, New York, October 4th 1943.

24 AOS in the Józef Piłsudski Institute, NY, J.Z. Dodatko’s file, W. Jędrzejewicz’s letter to J.Z. Dodatko, New York, October 15th 1943. 
W. Jędrzejewicz finally executed his plan to popularise the affairs of the Institute from 5th to 23rd November 1943. In Detroit, he delivered a lecture titled "Józef Piłsudski and the struggle for independence" (3 lectures) followed by visits to Toledo, Chicago (2 lectures) and Lorrain. Meetings in Gary, Milwaukee and Cleveland were also conducted. There was a special meeting for about thirty people in Detroit devoted to the Institute during which the Organizing Committee was established for Detroit and in its vicinity composed of Cukrowski, J.Z. Dodatko, Żukowski. The task of the Institute was to promote it and to collect subsidy fees and to transfer them to New York. ${ }^{25}$

During the meeting of the Organizing Committee of the Institute on December 16th, it was stated that only 48 members were recruited since the establishment of the Institute. Due to this fact, it was decided to intensify the search for new people because in addition there was the possibility of already registered members resigning, what was taken into account when making revenue forecasts for the years 1944/1945. At that time it was considered that the Institute should have at least 100 members in order to work smoothly and on condition that members would pay the fee immediately. Most frequently, the due fee was paid in instalments which did not help stabilise the cash flow. Therefore, at the request of H. Floyar-Rajchman, it was suggested to trawl for new members by drawing up a list of about 600 Polish refugees who would be specifically targeted. ${ }^{26}$

Correspondence with Piłsudskiites in London was maintained at that time, in particular, efforts were made to inform General Kazimierz Sosnkowski about progress in organizing the institute in New York and its activities. The simple and direct words of W. Jędrzejewicz addressed to Franciszek Sakowski prove this: "We would be very glad to receive General Sosnkowski's answer to our written notifying about the establishment of the Institute. In terms of our political works on this territory, the establishment of a research institute, which could document Polish problems calmly and objectively, was indispensable ... I would like you to have an opportunity to tell the General about issues concerning the Institute and inform him about these matters in the future." The information carried in the next letter is also typical. W. Jędrzejewicz - in reference to the previous letter - wrote among others "I do not know whether my letter was delivered to you. I enclosed material on the Józef Piłsudski Institute with the previous letter. Now I am enclosing this (a little bit more, together with a letter to the Chief, Piłsudskiites called Kazimierz Sosnkowski Chief) in writing. Please show this to the Chief when the opportunity occurs. We are very glad because of the General's letter, which pleased us. Apart from that please send the enclosed sets of documents (the statute and a report) to the following people Juliusz Łukasiewicz, Hauke-Nowak in Edinburgh, Władysław

25 Report of the Director of the Józef Piłsudski Institute in America, Annex no. 1 to minutes of the meeting of the Organizing Committee of the Józef Piłsudski Institute on December 16th 1943.

26 Minutes of the meeting of the Organizing Committee of the Józef Piłsudski Institute on December 16th 1943. 
Wielhorski in London, Eugeniusz Weese (Ministry of Foreign Affairs in London), Mrs. Marshal (i.e. Mrs. Piłsudska). He also informed about the works concerning printing Pisma Wybrane [Selected Writings] and the Constitution and asked: "If you have materials for the Institute, which need to be stored, send them to me (through Major [Marian] Chodacki)". He also asked: "Do you have the Virtuti Militari files which I brought to London and handed over to Mrs. Marshal (Piłsudska)?" In his response, F. Sakowski, realising the significance of the establishment of the Institute in New York, wrote that "I will take care to give you as much material as is possible. If I have a chance to talk to the Chief, I will report on the Institute's matters and its potential membership, which was pledged by Major Jawicz." He also informed about the archives of the Cross of Virtuti Militari, which were fully intact, having been brought over from Romania. However, Aleksandra Piłsudska, who was given the Order, gave it back in 1942 to the "Chief Authorities - about what she told me in October 1943. I was very anxious - that something would vanish, however, when I went to the Archives - I found everything in the best order and it was very helpful while working on the Statute of 'the Virtuti Militari'"' 27

After one year the Institute had 70 members. The membership was arranged by reference to big urban centres, in which there were bigger concentrations of Poles. Such a statement was presented in W. Jędrzejewicz's report. According to him there were twenty seven people from Detroit, twenty from New York, eight from Chicago, six from Cleveland, six from Philadelphia and three from other places which were not specified.

Jędrzejewicz also emphasized that one of the most important tasks of the Institute is to assist and advise those who are working on issues related to Polish history, in particular on problems related to recent years and as he emphasized, "In this regard, the Institute is in touch with the American Colonel of the General Staff, General G.L. McEntee (who came to the Institute in January 1944) working out the war's history of 1939 in Poland and works with students at Columbia University." As Jędrzejewicz wrote about Colonel McEntee's mission that the help in this kind of academic works is "one of the tasks of the Institute." Therefore, it was a great pleasure to acquaint the American historian with the bibliography which was being compiled, the documents and books related thematically (about 30 ), which were held by the institute. Some Polish documents were translated into English with the help of the Polish Information Centre. A lot of maps and sketches of operations were also made in the Institute. "Oral and written explanations of the director of the Institute completed the provided material. (As it was thought) based on the Institute's materials, Colonel McEntee would be able to introduce into Anglo-American source literature a serious and comprehensive study concerning the causes and course of the Polish-German war." Jędrzejewicz wrote on this subject among others "The issue is very important

27 AOS in the Józef Piłsudski Institute, NY, Franciszek Sakowski’s file, W. Jędrzejewicz's letter to F. Sakowski, New York January 5th 1944; ibidem, W. Jędrzejewicz's letter to F. Sakowski, New York February 14th 1944; ibid., F. Sakowski’s letter to W. Jędrzejewicz, London March 25th 1944. 
because for the second time no one would take it up. Hence, he needs help in order to make this book turn out well. Obviously, this is one of the tasks of the Institute, and our extensive bibliography made the Colonel's eyes bulge with surprise. Our library is already so rich that he took a large bundle of books with him. He will send me (the fruit of his research) chapter by chapter to look through." Jędrzejewicz stayed at Colonel McEntees's home in Albany between 8th and 9th April. As it was noted in the report, "a two-day discussion with the director Jędrzejewicz explained many problems connected with the plan of the book and the search for material." In addition, he emphasized that in the course of drafting his report, the director took part in conferences of the Emigre Commission Polish Institute of Learning and in a meeting concerning the reconstruction of libraries in Poland. Apart from that, he delivered thirteen lectures on historical topics in many cities. ${ }^{28}$

The authorities of the Institute were chosen on October 14th 1944. The director of the Institute, W. Jędrzejewicz, reminded those gathered that the previous authority was the Organizing Committee, appointed on July 4th 1943, which had four meetings in the year that followed. Because only a part of the members from this assembly lived in New York or nearby, but it kept in constant contact; he explained that the Committee was only called in exceptional situations when there was a need to adopt fundamental resolutions, which were very important and necessary for the existence of the Institute. For the first time in the Institute, the Council was chosen, which according to the statute since that moment took over the rights of the Organizing Committee.

The Council was constituted as follows: chairman - Stefan Łodzieski from Cleveland (Ohio); deputy chairman - Ignacy Matuszewski; treasurer - Józef Piech from Chicago; deputy treasurer -Piotr Kulpiński from Philadelphia; secretary - Marta Kozłowska from New York, all of whom were unanimously elected. W. Augustynowicz, J.Z. Dodatko, L.A. Kupferwasser from Chicago, H. FloyarRajchman and M.F. Węgrzynek from New York became members of the Council. The review board consisted of Wincenty Fabierkiewicz from Philadelphia, Lucjan Nowiński and Walery Starczewski from New York. ${ }^{29}$

The election of Stefan Łodzieski as chairman of the new institution became in the future unwritten tradition in appointing local pro-independence activists. Their knowledge of the environment, an ability to appeal for public subsidies and significant donations, thanks to which they supported the institution, were additional guarantees of its effective activities. Thus, there was the re-election of Franciszek Januszewski in 1951,

28 Report of W. Jędrzejewicz on the Second General Meeting of Members of the Institute, on October 14th 1944, p. 1; Report on the activity of the Institute for the period from April till June 1944, p. 3; Report on the activity of the Institute for the period from January 1st till March 31st 1944, pp. 3, 4; AOS in the Józef Piłsudski Institute, NY, J.Z. Dodatko’s file, W. Jędrzejewicz’s letter to J.Z. Dodatko, New York, February 24th 1944, p. 2; ibid., W. Jędrzejewicz's letter to J.Z. Dodatko, New York, February 10th 1944, p. 2.

29 ibid., p. 3; Report of W. Jędrzejewicz at the Second General Meeting of Members of the Józef Piłsudski Institute, October 14th 1944, p. 1. 
and then a long-lasting term of office of Henryk Korab-Janiewicz (3 terms of office) as well as Ignacy Nurkiewicz (2 terms of office) and Witold Kosicki. Beginning with Wiesław Domaniewski in 1960, Piłsudskiites from the post-war emigrants were the successive chairmen. In contrast to the position held by the chairman, the directors of the Institute were exclusively Piłsudskiites from Poland, and later on representatives of Americans of Polish descent in the 1980s and 1990s.

In connection with the stay of General Kazimierz Sosnkowski (an honorary member of the Institute) in New York, who was in Canada, where he intended to visit his sons, an extraordinary meeting of the Council took place on December 13th 1944 at 20.00 in the rooms of the Institute (K. Sosnkowski visited the Institute for two days because he saw rooms and talked to W. Jędrzejewicz also a day earlier on December 12th 1944). The chairman of the Council, Stefan Łodzieski, Ignacy Matuszewski, Piotr Kulpiński, Marta Kozłowska, Henryk Floyar-Rajchman, L.A. Kupferwasser, Włodzimierz Augustynowicz, W. Jędrzejewicz, Janina Węgrzynkowa and Franciszek Januszewski took part in this meeting. Members of the Institute living in New York and in the vicinity were also present in the room. The Polish Institute of Arts and Sciences of America [for short PIASA] was represented at that time by Jan Kucharzewski, a former Prime Minister, and prof. Oskar Halecki, the director. General K. Sosnkowski stated that he was always convinced that "Poles in the United States are profound patriots, people loving their fatherland, with which they did not break ties, people of generous heart and civic merits. And it is particularly nice for me that the first collective encounter with Poles in America is taking place in this Room, in the Institute, and that my first steps here are connected with the name of Józef Piłsudski, my great master and teacher." 30 The General also thanked the Institute's authorities for granting him the title of an honorary member of the Institute and stressed that setting up the Institute in exile, was a wise move. Ignacy Matuszewski, taking the floor at that time and welcoming the General, described the tasks facing the Institute and he stated among others "that the truth dies with dispelling the smoke screen over Poland. Instead of the truth there was the lie coming from east and west along with the army that even fighting against each other does not even stop fighting with Poland. The army, creeping like a thief, takes over the power from the Jagiellonians and gives it to Polish people. Today using the lie, they try to change our heroes into cowards and convince the Polish nation that heroism is vain. Using the lie, they try to besmirch our past. And using the lie, they can kill our future." ${ }^{11}$ W. Jędrzejewicz wrote about General Sosnkowski's reaction to the welcome with which he met in the Institute: "General Sosnkowski was very happy and glad that he could establish direct contact with a large number of members of the Institute." The outcome of this visit attracted greater interest of local Poles in the Institute, whose larger circle declared an intention to join the Institute. "The stay of General Sosnkowski and his favourable attitude to our institution also did

30 Report on the activity of the Institute for the year 1944, New York 1945, pp. 22-27.

31 ibid., p. 24-25. 
its job. We need to take advantage of our organizational work." ${ }^{32}$ he same year it was decided to change the office of the Institute. It was driven by excessive limitation of space because of the growing collections particularly of the library. Therefore, two rooms in the same building were rented on the first floor (115 East 22 Street, room no. 50). W. Jędrzejewicz wrote about this: "I had my hands full with the move of the Institute: [...] We take it together with the KNAPP, thus the price is the same till now. But we feel a lot better and we are calm. Transferring all the documents, archives, books and piles of newspapers took us a lot of time and brought chaos into the steady lifestyle of the Institute." 33

At that time it was also decided that on all publications of the Institute, a symbol, based on the occupied homeland's emblem of Poland-in-Arms. It shows an open book of the Constitution dated April 23rd 1935, a marshal's baton crossed with laurel leaves and the initials IJP (the Józef Piłsudski Institute). ${ }^{34}$ In the report the director of the Institute stressed that in the Institute's outside activity, in the reporting period there were about 20 meetings and lecturers, in which members of its authorities took part and during which issues connected with the Institute were discussed.

In the following months, the collections of the Institute, including its art department connected with the person of Józef Piłsudski, were still growing. Stefan Ropp, who was the General Commissioner of the Polish pavilion at the world exhibition in New York in 1939, gave a monumental sculpture in bronze made by Stanisław Ostrowski to the Institute. It was displayed in the main room of the Polish pavilion. Besides, Elwira Zachert-Mazurczyk placed in deposit a bust of Józef Piłsudski made of copper. The Institute also received an original portrait in oils of Józef Piłsudski on a horse by Wojciech Kossak. Thanks to the efforts of the Institute, a bust of Józef Piłsudski carved in granite by the American sculptor of Hungarian origin, Nicolai Koni, was handed over to the main sculpture exhibition room in a museum in Brooklyn. The statue was presented at many exhibitions in European capitals and cities in America. ${ }^{35}$ The history of the fate of the sculpture by Ostrowski is interesting. Because after the end of the world exhibition, the exhibition was kept in a public warehouse of Lincoln Warehouse Corp., at 1195, 3 Avenue in Manhattan, for what Stefan Ropp had to pay 3 dollars and 75 cents every month. On March 16th 1945 he handed over the sculpture to the Institute officially, which for lack of proper place for the sculpture had to be kept in the same warehouse taking on duty to pay for its storage. In June 1955 the management of the warehouse informed that since July one should pay 10 dollars per month. Therefore, D. Wandycz, the director, at

32 AOS in the Józef Piłsudski Institute, NY, Wincenty Fabierkiewcz’s file, W. Jędrzejewicz’s letter to W. Fabierkiewicz, New York December 27th 1944.

33 AOS in the Józef Piłsudski Institute, NY, Jan Zygmunt Dodatko's file, W. Jędrzejewicz's letter to J.Z. Dodatko, New York December 8th 1944.

34 ibid., p. 39.

35 W. Jędrzejewicz's report on the activity of the Institute for the year 1945 filed at the Third General Meeting of Members of the Institute, which took place in Gramercy Park Hotel on January 12th 1946; Report on the activity of the Józef Piłsudski Institute for the year 1945, New York 1946, p. 25. 
the meeting of the council of the Institute, proposed to make it available to a wider audience - to hand over the sculpture in a deposit to the Kościuszko Foundation located in New York at 15 East 65 Street in Manhattan. During an initial discussion on this topic before the meeting of the Council, S. Lenartowicz representing the Institute obtained from Stefan Mierzwa, the director of the Foundation, preliminary permission to take the sculpture in a deposit. Therefore, the Council of the Foundation after the adoption of the motion entrusted Lenartowicz with holding formal talks with the management of the Kościuszko Foundation which ended in complete success and in the same year the sculpture found its place in one of the main rooms. (At that time Lenartowicz's motion was unanimously accepted that the Institute will be placed in the list of the Kościuszko Foundation as a member paying a fee in an amount of 10 dollars.) Since that moment, because of the flow of time and human forgetfulness, the consecutive chairmen of both institutions confirmed in official writings who is the real owner of the sculpture. It was only after fifty years, on October 13th 1995, that the sculpture for the first time was placed within the walls of the Institute at 180, 2 Avenue in Manhattan. ${ }^{36}$

An important remark confirming the legitimacy of the establishment of the Institute were Jędrzejewicz's words included in a letter to J.Z. Dodatko: "Everyday reality indicates the rightness of our joint plans to set up the Institute. It becomes clearer that it will be the only Polish institution propagating historical truth about Poland. Because it is clear that it will not be possible to write in Poland about Poland, only about long lasting friendship between Poland and Russia. We will be responsible before history for the duty to keep documents and publications. It will be a copy of the Polish archives in Rapperswil in Switzerland, where word and thought of Poland for next generations were maintained for years. ${ }^{37}$ "

Jędrzejewicz also stated that in order to broaden contacts beyond the United Stated, the Council of the Institute appointed two new correspondent members Juliusz Łukasiewicz, a former Ambassador living in London, and Władysław PobógMalinowski, the well-known historian living in Paris. He stressed that "they have been cooperating with the Institute for a long time sending materials and publications." Apart from that he also claimed that more and more Polish communities in England, Italy and Palestine are interested in the work of the New York institutions

36 AOS in the Józef Piłsudski Institute, NY, Stefan Ropp’s file; AOS in the Józef Piłsudski Institute, NY, Stanisław Jordanowski’s file; Bulletin of the Józef Piłsudski Institute of America for the year 1945 and 1955; Krzysztof Langowski in: Bulletin of the Polish Army Veterans' Association in America (SWAP), "Weteran", "Rzeźba Józefa Piłsudskiego w Nowym Jorku”, New York, no. 902, March 1996, pp. 9-11; also in: minutes of the meeting of the Council of the Institute dated June 26th 1955, p. 3, whose author was secretary Jan Kowalski; also in: W. Jędrzejewicz's report on the Institute for the year 1945 filed on the Fourth General Meeting of Members of the Institute, which took place January 11th 1947, Annex no 3, p. 1.

37 AOS in the Józef Piłsudski Institute, NY, J. Z. Dodatko's file, W. Jędrzejewicz's letter to J.Z. Dodatko, New York June 30th 1945; “W sprawie Instytutu Józefa Piłsudskiego" in: "Nowy Świat”, New York March 3rd 1946, an extensive text devoted to the history of the Józef Piłsudski Institute in the interwar period as well as tasks realised by the Józef Piłsudski Institute of America (J.Z. Dodatko). 
and they are sending in valuable materials. However, one of the main problems was the inadequate rate of increase in the Institute's membership. There were 110 registered members, including two honorary members, five perpetual members (in 1945 there were two), nine supporting members (in 1945 there was one), three corresponding members (in 1945 there were two) and ninety one ordinary members (in 1945 there were ten).

Ignacy Matuszewski died of a heart attack on August 3rd 1946 in New York. His death was a big loss for both the Polish independence-orientated community in the United Stated and the Institute. This fact was also stressed during the Fourth General Meeting of Members of the Institute, which, in the absence of a chairman S. Łodzieski due to illness, was conducted by Kazimierz Wierzyński. During this meeting in the report, Jędrzejewicz stressed that: "The death of Ignacy Matuszewski, who was the soul and inspiration of the Institute, an inseparable companion and executor of our work and plans, is a severe blow to our institution." In addition, in order to bring Matuszewski closer to members of the institution, a small exhibition of his literary achievements was organized. There were, his books and pamphlets published in many countries, a collection of 657 articles written in the United States between the years of 1941-1946, letters and notes, as well as a set of the KNAPP Information Bulletin, of which Matuszewski took care until his death. Wincenty Fabierkiewicz, a member of the review board, who died at that time in Philadelphia was also mentioned on that occasion.

Later in a further part of the report, the director of the Institute stated that they were still developing cooperation with Polish academic institutions in America. The Polish Institute of Arts and Sciences of America and the Museum of the Polish Community in Chicago belonged to these institutions. This cooperation at that time consisted in an agreement as to the range of their interests. Jędrzejewicz stated that the Józef Piłsudski Institute is dedicated to the study of Polish contemporary history and the Institute of Arts and Sciences covers all branches of science, literature and the arts but it does not conduct studies of contemporary history. The Museum of the Polish Community rather studied relationships existing inside the Polish Community in America, it also researched issues connected with the activity of Tadeusz Kościuszko and Kazimierz Pułaski and created a museum which dealt with Polish culture. Cooperation with these institutions at that time consisted in exchanging publications, sharing duplicates of books and brochures. Jędrzejewicz stated that the Institute received "a number of valuable works, especially from the Museum of the Polish Community." The Institute was given a plaster cast of Józef Piłsudski’s hand by the wife of General Gustaw Orlicz-Dreszer, Anna. Five copies in bronze were made with the intention of selling them for five hundred dollars per copy. The director also emphasized that people from outside provided help with academic works produced in the Institute. In his report he stressed two cases, the first one of sister Maria Doloria (Felician order), who wrote a thesis on educational methods in Polish education, and the second by John Małecki, who was researching the prin- 
ciples of the Polish concordat. Also contact with the Kościuszko Foundation in New York was maintained, however, W. Jędrzejewicz unwillingly mentioned that: "the institution is currently working with Warsaw under the cover of helping the cause of Polish scholarship, with the exchange of scholars and the like." W. Jędrzejewicz's letter to T. Schaetzl, in which he presented an attempt of the Communists to influence the Polish Community by the new Communist Ambassador, Józef Wincewicz, was maintained in a similar tone: "Probably his task is to mould the Polish Community. He has not started that activity yet but I suppose that he will in the cultural field of the Polish Community and Poland." In his further words he stressed that: "The old Kościuszko Foundation with prof. Mierzwa at the forefront is on the same bridge", which sent books to Poland, brought scholarship holders from Poland to American universities and "blurs the boundary, which many would like to disappear. Indeed, Mierzwa claims that he does not recognize the Warsaw government, but it does not discourage representatives from Warsaw who bear various affronts very patiently and they do not offend." ${ }^{38}$

The coexistence of the Institute with the KNAPP was also reflected at meetings organized jointly. An example can be the words of W. Jędrzejewicz who stated among others that: "taking an advantage of the presence of delegates at the Convention of the KANPP, we would like to hold a meeting of the Council of the Józef Piłsudski Institute. I suppose that the meeting will take place on Saturday, November 16th at 5 p.m. At that time we will be able to leave the meeting room for a moment and devote an hour to the Institute's matters." However, at that time they decided not to organise the joint General Meeting of Members of the KNAPP and the Institute because - as Jędrzejewicz stated - "Experience has shown that joining these two conventions together gives bad outcomes. There is no time for that." In reality, the meeting of the Council took place on "Sunday, November 17th at 10 a.m., in the Institute's room." ${ }^{39}$ The words spoken by H. Floyar-Rajchman also reflect the strong cooperation of the Institute with the KNAPP and actions undertaken at the beginning of the existence of the Institute and its contribution to political initiatives in the independence-orientated environment. Hence, Rajchman stated at that time that "The Institute is not only an organizational unit. The greater the losses that Poland bears, the more tasks, not written in the statute, the Institute has to shoulder. We spoke on numerous occasions with Ignacy

38 W. Jędrzejewicz's report on the Fourth General Meeting of Members of the Institute, which took place on January 11th 1947 in Gramercy Park Hotel, Annex no 3, p. 1; Report on the activity of the Institute for the year 1946, New York 1947, pp. 1, 6, 8, 11; AOS in the Józef Piłsudski Institute, NY, Tadeusza Schaetzel's file, W. Jędrzejewicz's letter to T. Schaetzel, New York February 11th 1947, p. 2; ibidem, W. Jędrzejewicz's letter to T. Schaetzel, New York March 28th 1947, p. 2.

39 AOS in the Józef Piłsudski Institute, NY, Stefana Łodzieski’s file, W. Jędrzejewicz's letter to S. Łodzieski, New York November 4th 1946; AOS in the Józef Piłsudski Institute, NY, J.Z. Dodatko's file, W. Jędrzejewicz's letter to J.Z. Dodatko, New York November 12th 1946; AOG in the Józef Piłsudski Institute, NY, W. Jędrzejewicz, W. Jędrzejewicz's letter to Michał Krance, New York, November 12th 1946, zesp. 53, sygn. 14, p. 166. 
Matuszewski and Wacław Jędrzejewicz about how to change the Institute into a campaigning force. The efforts of the Institute and its members in 1947 have to contain more emotions, more feelings and much more sense of responsibility towards this than the emigrant community has done till now to defend the Polish causes and only now the fight will be undertaken." 40

At the same time it was intended to facilitate the arrival of Tadeusz Schaetzel and Janusz Jędrzejewicz to the United States, who were grounded in the Middle East. In one of the letters addressed to Stanisław Bielawski, living in Trenton in New Jersey, W. Jędrzejewicz giving details concerning those figures and the indispensable need to procure certificates required by the American authorities from a citizen of the United States (the so called Affidavit). Such a certificate inviting Tadeusz Schaetzel was supposed to be issued by S. Bielawski. Jędrzejewicz wrote at that time among others: "you can write in the affidavit that you know that Schaetzel, who held a responsible position in Poland and was a member of the Polish parliament, is distinguished by an impeccable character, honesty, moral virtues and good education. That he is a sincere democrat and he always opposed all totalitarian systems. You are fully convinced that his arrival in the United States not only will let you organise your life but it will also be of benefit for the society of this country." However, those attempts failed and J. Jędrzejewicz and T. Schaetzel went to London. Similar efforts, which were successful, were taken in the case of General Wincenty Kowalski. General Stefan Łodzieski issued a suitable certificate for the American authorities. W. Jędrzejewicz also wrote about the General "After leaving the prisoner of war camp, he stayed in France for a short time, and then in London. In order to remain independent and not be subject to the relations that predominated there, he did not stay there. Thanks to the courtesy of the American authorities, he received a visitor's visa and he has stayed here for many months. Currently, the visa has expired but he has received an extension of his visa. Following the advice of his friends in Washington, he takes steps to receive an American visa. For this purpose two Affidavits of support are needed. This is the reason why I am addressing you." Attempts to bring Władysław Pobóg-Malinowski to the United States were also made. For the first time he wrote about a possibility of his arrival in New York in July 1945, and W. Jędrzejewicz answered that: "all of us gathered here will be glad to see you in Washington in joint work under old and victorious banners. Therefore, we will try to do everything to make your arrival easier." Efforts to obtain the necessary certificates for the Immigration Office were quickly undertaken in America. However, there were big problems - as W. Jędrzejewicz explained - "people did not want to reveal their incomes. Finally, the Wierzyńskis managed to obtain for you a very good Affidavit from Michał Kranc." Later W. Jędrzejewicz also invited him to benefit from materials gathered in the Institute, encouraging him to transfer the submitted documents from the American Consulate in Paris to the one in London "so you should not lose your temporary priority status. I am not sure, and

40 H. Floyar-Rajchman's speech during the Fourth General Meeting of Members of the Józef Piłsudski Institute of America on January 11th 1947, Annex no. 7, p. 6. 
here nobody knows that, but I presume so. It would be really good if you were able to come here and work a little bit at the Institute." 41

In the activity report of the institution in New York we can find information that its work was meeting a great response the United States and beyond, wherever there are larger Polish emigrant communities. Cooperation, conducted with numerous centres, in collecting documents and publications created more opportunities for the Institute to communicate with people or institutions from different countries. In some of those centres the cooperation of many people was possible, as a result of which the idea of establishing branches of the Institute in New York outside the United States occurred. It turned out that American law did not have anything against it "as long as the branches were established in accordance with local laws on associations." Therefore, on March 19th 1947, a new branch of the Institute in London was established by W. Bortnowski, Janusz Głuchowski, Tadeusz Münnich, K. Iranek Osmecki and others. The London branch developed a discussion activity, gathered archives and publications, and prepared the historical periodical "Niepodległość". Attempts to organise a branch of the New York Institute in Ankara on the initiative of the former Polish Ambassador, Michał Sokolnicki, were also undertaken. This issue was raised several times. In one of his letters, M. Sokolnicki stated that: "The issue concerning a section of the Institute will be handled by me in Istanbul, where I am going within 3-7 weeks. The Polish Community has shrunk so much that it would not expand outside a company and a couple of units. I would like to know how I should deal with membership fees: is there a less 'American' scale for members from other countries?' In a response W. Jędrzejewicz wrote that he understood the section of the Institute on the territory of Turkey as "a completely independent unit with its own statute, rules, own payments and other regulations concerning its authorities and the like." Only the name was supposed to be shared with the Institute in New York "The Józef Piłsudski Institute of America for Research in the Contemporary History of Poland. A Branch in Turkey." Additionally, the institution in New York cared about appointing its member as a delegate to the authorities of this branch with "the right to suspend important resolutions till the moment the resolutions have been approved in New York." However, it soon turned out that because of restrictions imposed by Turkish law "a circle of friends of the Józef Piłsudski Institute" could only been established. It was decided that the main task was to rely on Turkish cooperation on research on the contemporary history of Poland, and also search for materials and books for the Institute. Sokolnicki

41 AOG in the Józef Piłsudski Institute, NY, Wacław Jędrzejewicz’s file, W. Jędrzejewicz’s letter to J. Łukasiewicz, New York, January 4th 1946, zesp. 53, vol. 2, p. 95; AOS in the Józef Piłsudski Institute, NY, Stanisław Bielawski’s file, W. Jędrzejewicza’s letter to S. Bielawski, New York March 8th 1946; AOS in the Józef Piłsudski Institute, NY, Stefan Łodzieski’s file, W. Jędrzejewicz’s letter to S. Łodzieski, New York January 22th 1947, p. 36; AOG in the Józef Piłsudski Institute, NY, Władysław Pobóg-Malinowski, W. Pobóg-Malinowski’s letter, Paris July 3rd 1945, zesp. 85, sygn. XLII/A/1-1, ibid., W. Jędrzejewicz’s letter to W. Pobóg-Malinowski, New York August 3rd 1945, sygn. XLII/A/1-2; ibid., W. Jędrzejewicz's letter to W. Pobóg-Malinowski, New York October 20th 1945, sygn. XLII/A/1-5, ibid., W. Jędrzejewicz's letter to W. Pobóg-Malinowski, New York October 18th 1947, sygn. XLII/A/1-69, p. 296. 
emphasized that: "the existence of the 'Circle' will be in fact confidential and even in letters I will be talking about it moderately. Apolinary Kiełczyński, Ciafer Seydamet and I will be at the centre of the 'Circle. We will keep an eye on a few other people." 42

It was also planned to establish a branch of the Institute in Paris because that was where W. Pobóg-Malinowski and Wacław Grzybowski lived, with whom Aleksander Kawałkowski could work. As Jędrzejewicz suggested that "they could devote some time to discuss old issues, write and search for their own and other archives, search for their documents from the present war, etc - just dealing with thinking about documents. Lecturers or papers could supplement this work and a research workshop could be slowly formed, which is so indispensable in today's world." W. Jędrzejewicz and General Gąsiorowski dealt with correspondence in terms of establishing another branch this time in Nice. In one of the letters he wrote among others "that this is because of a great number of our higher commanders gathered there." Jędrzejewicz also hoped to organise another branches in Rio de Janeiro in Brazil, in Palestine, in Rome and in Switzerland. In one of the letters addressed to a former naval attaché of the Republic of Poland in Brazil, Bohdan Pawłowicz proposed to organise branches of the Institute in Rio de Janeiro. He wrote to Piotr Górecki about the same issue that "the purpose of this branch was to create on your territory an apparatus of the Institute which would think about us in terms of collecting materials concerning the contemporary history of Poland and sending them to us. Maybe you could find amateurs who would be more seriously interested in terms of finances giving you support in your work. Besides, our communication would benefit because our organizational frameworks would require it. This also means something. Not knowing your conditions I cannot suggest any more. Maybe we could correspond in this matter again. However, those proposals have not been undertaken yet. Finally, in San Francisco the Society of Józef Piłsudski was established. Its members were among others Czesław Świrski and Karol Polakiewicz." ${ }^{33}$ Contact with a Piłsudskiite "Team" in the Middle East and the Labour Association for the Country appointed from it was very quickly established. Janusz Jędrzejewicz, Wiktor Tomir Drymmer and Tadeusz Schaetzel worked there. ${ }^{44}$ Cooperation was also started on September 28th 1942 with the established Labour Association of Rebuilding of Poland in Teheran. Konstanty Rdułtowski, count Michał Tyszkiewicz, Władysław Jaszczołt and Bohdan Kawecki, a former vice-director of the Institute

42 AOG in the Józef Piłsudski Institute, NY, Michał Sokolnicki, M. Sokolnicki’s letter to W. Jędrzejewicz, Ankara June 27th 1947, zesp. 91 T(1), t. 44-46b; ibid., W. Jędrzejewicz's letter to M. Sokolnicki, New York July 8th 1947, t. 45g, p. 1; ibid., M. Sokolnicki’s letter to W. Jędrzejewicz, Istambul September 18th 1947, T(1), vol. 44-46b.

43 AOS in the Józef Piłsudski Institute, NY, Bohdan Pawłowicz’s file, W. Jędrzejewicz’s letter to B. Pawłowicz, New York June 3rd 1947; J. Cisek, "Instytut Józefa Piłsudskiego w Ameryce i jego zbiory", Warsaw 1997, p. 23; AOS in the Józef Piłsudski Institute, NY, Piotr Górecki’s file, W. Jędrzejewicz's letter to P. Górecki, New York September 15th 1947, p. 1.

44 ARZ in the Józef Piłsudski Institute, NY, the Labour Association for Country, Zasady Programowe Związku Pracy dla Państwa założonego przez Zespół Piłsudczyków na Srodkowym Wschodzie, Jerusalem July 15th 1944, zesp. 114; J. Cisek, op. cit., p. 22. 
in New York were active in this Association. Cooperation with the Team was also continued when the group moved to Lebanon. It occurred long before establishing the Union of Poles in Lebanon (May 24th 1946), whereas the press and publications published on this territory as well as the documents it possessed were sent to the collections of the Institute in New York. Appeals for establishing cooperation with the Institute appeared in "A Pole in Lebanon." The above mentioned contacts were supposed to enable to build another branch of the Institute exactly on this territory. The possibility for realising these conceptions was considered by W. Jędrzejewicz in correspondence with Tadeusz Schaetzel and General Tadeusz Kasprzycki. None of these succeeded as the only obstacle was another displacement of the people involved. ${ }^{45}$ The undertaken organizational plans came to nothing because of constant migrations of both military persons and politicians, especially in the direction of London, where the only success was actually achieved. ${ }^{46}$

In a discussion, which developed in a later period, on the activity of the Institute, an issue concerning an ongoing trial in Warsaw against the former director of the Institute, Colonel Wacław Lipiński, was raised. Lipiński's words were quoted at that time that: "we write down Polish history, which was created by Piłsudski." Therefore, it was stressed that the research work performed by the Institute in New York was particularly important at that time when "Polish history is being distorted." Colonel Lipiński realised the fact when during his trial he said "I wanted the world to know what was going on with the Polish society." Juliusz Łukasiewicz stressed in a discussion that the most important task of the Institute "is to intensify work on the contemporary history of Poland, systematically distorted by factors hostile to Poland both foreign and home-grown." As an example, he quoted Stanisław Mikołajczyk's book, in which the author claimed that Piłsudski searched for appeasement with Germans, remaining silent that it was Piłsudski who tried to organize a preventive war with Germans. "This fact serves as evidence of how publishing real things is needed and how important is the existence of an institutions which can carry out this work." 47

Activists of the Institute already made an attempt at the turn of 1946/1947 to help gather money that would help with the departure of Wacław Lipiński from Poland.

45 ARZ in the Józef Piłsudski Institute, NY, Team Work on Reconstruction of the Country, zesp. 114, vol. 1-3; Instytut Józefa Piłsudskiego w Ameryce, "Polak w Libanie", Beirut August 15th 1947, no. 14; Instytut Józefa Piłsudskiego w Ameryce, ibid., September 1st 1947 no. 15; AOS in the Józef Piłsudski Institute, NY, Tadeusz Kasprzycki's file, General T. Kasprzycki’s letter to W. Jędrzejewicz, Bejrut July 4th 1947; AOS in the Józef Piłsudski Institute, NY, Tadeusz Schaetzl's file, W. Jędrzejewicz's letter to T. Schaetzl, New York, April 4th 1947.

46 AOS in the Józef Piłsudski Institute, NY, Wacław Grzybowski’s file, W. Jędrzejewicz’s letter to W. Grzybowski, New York April 17th 1947, p. 2; AOS in the Józef Piłsudski Institute, NY, Stefan Łodzieski’s file, W. Jędrzejewicz's letter to S. Łodzieski, New York April 25th 1947, p. 2.

47 Report on the activity of the Institute for the year 1947, New York 1948, p. 4, 5, 10, 11; on establishing the Institute in London the Institute in New York informed the Polish émigré community in a press announcement dated April 26th 1949, and publish among others in: "Polish Daily", Detroit May 6th 1949; AOS in the Józef Piłsudski Institute, NY, J.Z. Dodatko's file, W. Jędrzejewicz's letter to J.Z. Dodatko, New York March 3rd 1947, p. 420. 
However, he refused to leave the country because he counted on the possibility to continue a political activity in Poland ruled by the Communists. An attempt was made in New York, as exemplified in correspondence with H. Floyar-Rajchman, in which he stated "Do be kind to put aside everything which takes you time and energy and make the maximum effort to help Wacław [Lipiński] who has been in hospital for some time. I do not know how long the disease will last. I think about recovery. Do be kind to inform Władek [Bortnowski] and advise together how to help cure the disease and how to organise his recovery." The author simultaneously advised not to give too much publicity to the whole intention: "in order not to do harm the sick person. However, the mobilization of resources is needed. [...] Therefore, do be so kind on behalf of yourself and all of us to have a personal conversation with [Władysław] Anders and tell him that we pay special attention to issues concerning the recovery of our cousin. Let him do what he wants but he has to understand and treat this incident as a matter of extraordinary effort and great concern." After arresting him, attempts to help him were undertaken. Similar efforts concerning the departure of the former Prime Minister, Kazimierz Świtalski, from Poland (he definitely refused emigrating) were made, as is evidenced in the preserved correspondence between H. Floyar-Rajchman and Aleksander Bobkowski staying in Geneva. In a later period, an interesting reason aimed at releasing Polish activists and politicians from prison including also K. Świtalski, was W. Jędrzejewicz's letter to W. Pobóg-Malinowski, which mentioned the issue of returning the treasures of Wawel Castle from Canada to the country. Jędrzejewicz inclined to their transfer to Cracow but - he emphasised that - we should at this point "bargain the release of a number of people from Polish prisons (Świtalski and others). Keeping the treasures here in Canada in order to destroy them and that nobody could see them does not make sense. In Poland they will have an influence at least on the maintenance of our national identity and national pride, and thus they will play an anti-Communist educational role in terms of the Internationale. Money could not be taken from Warsaw for that. The only thing that remains is the slave trade. Immoral but practical. This can be done slowly, they could grant gradual amnesty in Warsaw or release the mentioned people and then let them go abroad. Then the government would return tapestries and other treasures." 48

48 AOG in the Józef Piłsudski Institute, NY, Władysław Bortnowski’s, H. Floyar-Rajchman’s letter to J. Łukasiewicz, New York January 10th 1947, zesp. 37, sygn. V/vol. 3, p. 1; AOS in the Józef Piłsudski Institute, NY, J. Z . Dodatko's file, W. Jędrzejewicz's letter to J.Z . Dodatko, New York September 5th 1946, p. 2; W. Jędrzejewicz's report on the Fifth General Meeting of Members of the Institute, January 10th 1948, Annex 3, p. 1; AOS in the Józef Piłsudski Institute, NY, Aleksander Bobkowski’s file, H. Floyar-Rajchman's letter to A. Bobkowski, New York June 13th 1946; ibid., A. Bobkowski's letter to H. Floyar-Rajchman, Genewa January 12th 1947; ibid., A. Bobkowski’s letter to H. Floyar-Rajchman, Geneva February 13th 1947; ibid., W. Jędrzejewicz's letter to A. Bobkowski, New York January 15th 1947; ibid., A. Bobkowski's letter to H. Floyar-Rajchman, Genewa February 28th 1947; ibid., A. Bobkowski’s letter to H. Floyar-Rajchman, Genewa March 9th 1947; ibidem, H. Floyar-Rajchman's letter to A. Bobkowski, New York March 21st 1947; AOG in the Józef Piłsudski Institute, NY, Władysław Pobóg-Malinowski’s 
The year 1948 was even worse for the Institute. It was primarily connected with a chronic lack of funds for its maintenance. Jędrzejewicz wrote about this: "I do not have a secretary now and I have to type on a typewriter myself, arrange archives and books as well as magazines, give books to a binding, collect fees, do bookkeeping and do hundreds of petty everyday things [...] that I do not have the possibility to go to libraries and study - which I should do." ${ }^{49}$ Still there was a problem with collecting membership fees, donations decreased, subventions also failed, for which the authorities of the Institute were striving for in the Congress of the Polish Community in America. The Institute making efforts before the Convention of this institution in May 1948 in Philadelphia put forward a motion for an annual subsidy of 6100 dollars. W. Jędrzejewicz, the secretary Jan Kowalski and a member of the Council Colonel Jan Walla went to the Convention at that time. The motion of the Institute was accepted by the appropriate commission of the Congress, then by the section and finally it was passed by the Plenum of the Chamber. Despite this, the new Board of the Congress did not action the motion and the Convention's resolution remained a dead letter. The Institute at that time could only have some support of the KNAPP that had already given the Institute a subvention of 1200 dollars per year several years earlier. However, this organization, because of its own financial difficulties, was not able to fulfil its obligation. In connection with the problems of the Institute, W. Jędrzejewicz also wrote to General F. Maciszewski, who lived at that time in River Forest in Illinois. Jędrzejewicz was thinking how to organise the fundamentals for the further existence of the institution in the form of an office, a telephone and the most necessary expenses. For this purpose, there was a plan at the Institute to organise a fund, which would allow for "the further existence of the Institute and to provide at least sums which are indispensable for its survival. Indeed, we hope that there will be sums, which would again allow for the activity of the Institute to improve. We mean the Congress of the Polish Community and we will make all efforts in this direction. However now, in connection with the action of [Stanisław] Mikołajczyk, there are weak possibilities to gain any help." In another part of the letter, Jędrzejewicz asked for financial support because as he emphasised "I know that so far you did not refuse your help believing that the sums, which we ask about, went on different issues shared by both of us." About this issue, he also wrote to Władysław Pobóg-Malinowski, emphasising that the Institute was trying at that time for a grant subvention from the Congress of the Polish Community in America. "The Convention in Philadelphia carried resolutions at its plenum, recommending to grant the Institute a subvention of 6100 dollars. But would Rozmarek pay that to us - I really doubt it, because his political conflicts are important here, namely our actions against Mikołajczyk." Jędrzejewicz turned to members of the

file, W. Jędrzejewicz’s letter to W. Pobóg-Malinowski, Wellesley May 21st 1951, p. 2, p. 455, zesp. 85, ibid., W. Jędrzejewicz's letter to W. Pobóg-Malinowski, Wellesley February 13th 1955, pp. 525, 526.

49 AOG in the Józef Piłsudski Institute, NY, Michał Sokolnicki, W. Jędrzejewicz’s letter to M. Sokolnicki, New York January 24th 1948, p. 1, zesp. 91, vol. 45g. 
Polish government in London for financial support for the Institute. It is reflected in an exchange of correspondence with Tadeusz Gwiazdowski, who stated that "I exerted all my energy here in order to provide you with even the smallest subvention. Unfortunately, I met with a categorical refusal: nowadays, the government cannot give subventions to any institution. That is the reply I got." 50

A major difficulty of the activity of the Institute was Jedrzejewicz's departure to work as a lecturer, which he started at the end of September 1948 in Wellesley College near Boston (Massachusetts). After his resignation, Irena Grabowska continued temporary work thanks to which the institution in New York could survive difficult moments." 51

He wrote to Władysław Pobóg-Malinowski about his new work place in Wellesley College and the reasons, for which he had to take it up. There he received a position of "a professor of Slavic studies, mainly the Russian language and Slavic literature (in English) [...] this is a college for girls. My task is to clear their minds in terms of European issues. I would be able to tell a lot about Poland and Russia. The work is interesting in this respect. Wellesley is about five hours from New York so I can commute here and supervise the Institute." 52

General Kazimierz Sosnkowski arrived in New York in October 1949 for the first time since 1944. He was invited to the Pułaski Parade (the first one took place in 1938), which is held annually, always on the first Sunday of this month. He was also present at a meeting of the Council of the Józef Piłsudski Institute on Saturday, October 8th (between 2 and 3 p.m. tea and biscuits were served). This stay was a kind of "a breakthrough in the blockade which, as [the General] stated, is taking place in Canada because of difficulties with visas to travel to the United States."

In 1949 the Institute based its work entirely on voluntary work. In the report prepared by the treasurer, Ignacy Nurkiewicz, we can find information that expenses considerably decreased compared to the previous year by 2057.45 dollars and they amounted to 1344.72 dollars. It was achieved by supporting activities of the Institute with the voluntary cooperation of a group of people from the authorities of the institution. The secretary of the Council, Jan Kowalski from New York, was preoccupied at that time with the management of the office, Marian Chodacki helped him. Revenues in the reporting period amounted to 1807.73 dollars what meant a decrease of 253.02 dollars compared to the previous year. As a result, during 1949

50 W. Jędrzejewicz's report on the Sixth General Meeting of Members of the Institute, which took place on January 16th 1949 in Woodrow Wilson Foundation Room at 45 East 65 Street in New York, pp. 1, 2; AOG in the Józef Piłsudski Institute, NY, Wacław Jędrzejewicz’s file, W. Jędrzejewicz’s letter to General F. Maciszewski, zesp. 53, vol. 14, pp. 201, 202; AOG in the Józef Piłsudski Institute, NY, Władysław Pobóg-Malinowsk’s file, W. Jędrzejewicz's letter to W. Pobóg-Malinowski, New York June 25th 1948, zesp. 85, sygn. XLII/A/1-84, p. 334; AOS in the Józef Piłsudski Institute, NY, Tadeusz Gwiazdowski's file, T. Gwiazdowski’s letter to W. Jędrzejewicz, London February 16th 1948; ibid., W. Jędrzejewicz’s letter to T. Gwiazdowski, New York March 9th 1948.

51 ibid., p. 2.

52 AOG in Józef Piłsudski Institute, NY, Władysław Pobóg-Malinowski’s file, W. Jędrzejewicz’s letter to W. Pobóg-Malinowski, New York June 25th 1948, zesp. 85, sygn. XLII/A/1-84, p. 334, zesp. 85, sygn. XLII/A/1-84, p. 334. 
surplus of income over expenses of 463.01 dollars was achieved. The state of finances on December 31st 1949 amounted to 753.47 dollars. ${ }^{53}$

In regard of the voluntary help for the Institute from Marian Chodacki, H. FloyarRajchman wrote to the chairman of the Institute, asking to obtain consent to "to pay Marian Chodacki 100 dollars from the funds of the Institute." This money was a kind of reimbursement of expenses, travel, and the like, connected with his work for the institution "for the six-month period" commencing in January. Floyar-Rajchman mentioned Chodacki's significant donation to the Institute, he - in order to keep it going - was forced to work night shifts at the Waldorf Astoria Hotel at that time. This job was poorly paid - about 30 dollars per week. Despite significant "fatigue he does not neglect his work in the Institute, where he stays in the afternoons before going to work his night shift." 54

\section{The issue of organizing the archives and library of the Institute}

Wacław Jędrzejewicz, before organizing the Institute, dealt with completing the archival and library collections gathered in the KNAPP during the activity of this organization. He mentioned this in a letter to J.Z. Dodatko, where he stated that he constantly worked every week for two evenings in the National Committee, where, apart from discussing current political issues, he was busy preparing archives of the gathered press and publications, which "would be historical material for a researcher of that time. I have much trouble with that because there is a huge mess. Soon there will be an organizational instruction about colleting and storing documents and materials to their central arrangement according to the latest scientific principles binding in modern archives." 55

Later, joining the activity of the Institute's office, Jędrzejewicz also started collecting the bases of the archives and library. In the report of the Organizing Committee of the Józef Piłsudski Institute dated December 16th 1943 it was stated that the archives contained documents, which were organised in files, and among them particular attention should be paid to the underground writings of the Camp of Fighting Poland in August 1943; J. Piłsudski’s conversation with Ambassador Potocki in May 1933; an appeal of the Committee for National Defense to President Woodrow Wilson in 1917; the report on the activity of the National League for the year 1900/1901 (Roman Dmowski's manuscript). It was also stated that conversations with the Archives Commission of the Committee for National Defense were

53 Ignacy Nurkiewicz's report on the Seventh General Meeting of Members of the Institute, which took place on January 29th 1950 in Woodrow Wilson Memorial Foundation at 45 East 65 Street in New York.

54 AOS in the Józef Piłsudski Institute, NY, Stefan Łodzieski's file, H. Floyar-Rajchman's letter to S. Łodzieski, New York June 13th 1949, p. 1.

55 AOS in the Józef Piłsudski Institute, NY, J. Z. Dodatko’s file, W. Jędrzejewicz’s letter to J.Z. Dodatko, New York March 21st 1943. 
conducted in Chicago (among others by J.Z. Dodatko) on making the archives available to research in this organization. ${ }^{56}$

Procedures to obtain the archives of the Committee for National Defense by the Institute were arduous and dragged on for several years. J.Z. Dodatko encouraged W. Jędrzejewicz in writing to force, in particular, Eleonora Paradzińska, who held the archives in deposit. Jędrzejewicz, during his tour in Chicago in December, talked personally to E. Paradzińska about this. However, she stated that the decision about transferring the collection to the Institute could not be made by herself and she suggested that the case should be presented in correspondence to the secretary of the Archives Commission of the Committee for National Defense, Stanisław Orszula living in Chicago and he would present the above issue at the convened meeting. ${ }^{57}$ Also Wacław Gawroński, who talked to E. Paradzińska about this issue during an anniversary show [in Polish: akademia, a sort of review at which, typically, eminent luminaries of the local Polish community deliver exceedingly long speeches, child prodigies play bits of Chopin on slightly out of tune pianos, and energetic youths aged 10 to at least 35 perform a vigorous krakowiak, mazurka or, yes, even an obertas which brings the house down -ed] organized on May 12th 1944 in Chicago, was engaged in efforts to transfer the archives. In his report to W. Jędrzejewicz, he stated that "more efforts will be needed to progress the issue of the archives of the Committee for National Defense, and she puts forward some administrative and formal objections which do not have any sense. We promised ourselves to talk about this subject but please give us some time." In his letter he also responded to Jędrzejewicz's proposal to write "The History of the Committee for National Defense", in gratitude for its work, and suggesting that it should be written by "a local person, with the reservation that the committee should exercise control over its content and proceed with caution."

Soon after that J.Z. Dodatko as a member of the Archives Commission of the Committee for National Defense wrote a letter to Stanisław Orszula, in which he stressed that the issue of publishing a monograph concerning the history and activity of the Committee for National Defense remained in abeyance for several years. Therefore, together with the second member of the Archives Commission of the Committee for National Defense, he encouraged the powers that be to pass the archives on for the use of the Józef Piłsudski Institute and at the same time became members of this institution. The right decision of the organization was made in 1951 and the collections to the Institute were handed over in three big shipments, the last of which arrived in November 1955. Mrs Paradzińska took care of this. They were aware of the value of the archives which were handed over at the Institute in New York. It was a valuable reason to highlight for the benefit of Poles in America their contribution to the struggle for independence of their country of origin which had

56 Report of the director of the Józef Piłsudski Institute on the meeting of the Organizational Committee on December 16th 1943.

57 AOS in the Józef Piłsudski Institute, NY, J.Z. Dodatko's file, W. Jędrzejewicz's letter to J.Z. Dodatko, New York December 3rd 1943. 
been torn apart by three partitioning powers. It consisted among others of materials concerning the voluntary recruitment to the Polish Legions conducted on the territory of the United States (including among others personal applications, lists of names of volunteers, amounts of funds gathered and spent on this purpose, instructions for volunteers, etc.). There was also extensive correspondence from that period and there was J. Piłsudski's original letter to the Committee for National Defense dated May 11th 1915 with thanks for a banner for the Legions made by Polish women in Chicago and handed over after the battle of Konary in $1915 .{ }^{58}$

Before all the papers of the Committee for National Defense were handed over to the Institute, J.Z. Dodatko handed over part of them, which he had kept at home. I. Matuszewski, confirming the receipt of the package, which he personally brought from Detroit, confirmed its contents. Jędrzejewicz wrote that the package contained " 2 brochures, 20 letters, cards, appeals, diplomas and other documents, 73 press cuttings and miscellaneous editions of magazines. (He emphasized that in those materials there are) many first-class materials such as documents concerning the Committee for National Defense, W. Sieroszewski's letter, materials regarding awards of the Cross of the Legions and the like." ${ }^{59}$

In the report of the director, W. Jędrzejewicz, in December 1943, we can find the first information about the condition of both the archives and the library. Well, he noticed at that time that the previous documents had been organised in files and among them we should pay particular attention to the "writings of the Camp of Fighting Poland in August 1933, the appeal of the Committee for National Defense to Woodrow Wilson in 1917, the report on the activity for the period of 1900/1901 of the National League (Roman Dmowski's monograph), phonographic recordings with the speech of General Władysław Sikorski in Chicago and many others." The library at that time had about 200 volumes, almost all of which were already catalogued as well as collections of periodicals and journals (27 titles were gathered). According to Jędrzejewicz, the entire set of "Monitor Polski" published in a period of stay of the Polish government in France and Angers in the years 1939-1940 were among the most valuable collections. Among others, he mentioned the following titles: "Times", "Atlantic Monthly", "New Europe", "Free Europe", "The Nation", "Foreign Affairs", "Nasza Trybuna", "Nasz Świat”, "Myśl Polska”, “Tygodnik Polski”, "Dziennik Polski" published in London, "Dziennik Polski" published in Detroit,

58 AOS in the Józef Piłsudski Institute, NY, J.Z. Dodatko' file, J.Z. Dodatko's letter to the Archives Commission of the Committee for National Defense, Detroit (Michigan), December 14th 1943; AOS in the Józef Piłsudski Institute, NY, Wacław Gawroński, W. Gawroński’s letter to W. Jędrzejewicz, Chicago May 24th 1944; Bulletin of the Józef Piłsudski Institute no 2, March 1952, p. 2; Announcement of the Józef Piłsudski Institute, December 1955, p. 2.; Report filed on the General Meeting of Members of the Institute on May 12th 1956, p. 3; AOS in the Józef Piłsudski Institute, J.Z. Dodatko’s file, "Dziennik Polski", Detroit, text "Raport Komisji Likwidacyjnej Archiwum KON", January 14th 1946; ibid., Jan Kowalski’s letter to J.Z. Dodatko, New York August 27th 1949.

59 AOS in the Józef Piłsudski Institute, NY, J.Z. Dodatko’s file, W. Jędrzejewicz's letter to J.Z. Dodatko, New York April 6th 1944. 
"Nowy Świat" published in New York, "New York Times" and others. Additionally, in the library of the Institute there were materials published by different institutions, such as the Polish Information Centre (published by the Polish government in London), the Catholic Press Agency, the KNAPP, the Pułaski Foundation and many others. The library of the Institute was run by Pauline C. Ramsey, who was also a librarian working at Columbia University in New York at that time. For her work, she was paid 20 dollars per month. She was compiling a detailed bibliography of modern Polish history, which in December 1943 counted "about 1550 cards; apart from that bibliography concerning J. Piłsudski amounts to about 250 cards." ${ }^{\prime \prime}$

In the report for 1944, we can read that the archives containing separate problems based on the materials in the form of documents (originals or copies), letters, cuttings, memoires and photographs were created. J.Z. Dodatko from Detroit handed over important documents (valuable letters and souvenirs) from the years of 1920-1922. Among the gathered materials, it was stressed that considerable space was devoted to texts concerning the activity of the Polish Community in recent years and above all materials concerning the KNAPP, the Coordinating Committee for Polish Associations in the East and the Polish American Congress. In addition, this section was supplemented by a collection of cuttings from American and Polish press published in exile, which logged the most important events in the war period. They also collected the whole correspondence conducted by the Institute, minutes of meetings, the authorities of the Institute, etc. In 1944, in order to complete the materials which were in the archives, as W. Jedrzejewicz stated: "current events in international politics require the constant observation of the Institute in terms of documentation of these phenomena, causing the necessity to step back and to compare them with the events of more than 100 years ago. Works in libraries have become insufficient" and therefore, it was decided to buy photocopies of documents for the Institute, which were indispensable to realization of the research that was being conducted. In this way, the correspondence, of the Minister of Foreign Affairs of Great Britain, Castelreagh, conducted with the Russian Emperor, Alexander I in 1814 during the Congress of Vienna concerning Polish issues, was acquired. The purchased set consisted of 20 photographs of a large size, which were made of an old English edition. The incurred cost amounted to 7.85 dollars at that time. The second expense was the purchase of Leonard Chodźki's work "Recueil des traites, conventions et actes diplomatiques concernant la Pologne 1762-1862." It was a collection containing 1171 pages of treaties, conventions and diplomatic acts relating to Poland. It included a set of international correspondence on the partitions of Poland, the texts of the partition treaties were organised according to date and type - letters, memorandums etc. There were also documents concerning the Polish issue during the period of Napoleon I, the Congress of Vienna, the November Uprising, until the

60 Report of the director of the Józef Piłsudski Institute for the meeting of the Organizing Committee on December 16th 1943, pp. 2, 3. 
closing date of 1862 . W. Jedrzejewicz emphasized that "the splendid collection in the French language became indispensable material in the work of the Institute. The search for a rare book to be purchased did not give any results, therefore, it was decided to take pictures of (the whole book). This gave 594 photostats, the price of which (reduced for the Institute by a photographer's shop of Columbia University) amounted to the considerable sum of 151 dollars." The library at that time had 650 catalogued books. Among them, as the director stated "we have many valuable 'rare books"' The prepared bibliography contained at that time 2695 pages arranged according to authors and 1864 pages arranged according to sections. ${ }^{61}$

Many archival materials including documents, books and brochures were gathered by Poles in exile for many years. Poles were not willing to hand them over to the collections of the Institute in New York. W. Jędrzejewicz mentioned one such event when writing about his stay concerning issues of the Institute in Philadelphia, where at "reverend E. Bączkowski's, I found a whole set of "Wici", all bound yearbooks. He does not want to give them to the Institute but he promised to lend them if necessary. We have to keep records of books where they are." 62

An extremely valuable shipment which was sent to the archival collections of the institution are fragments of prewar collections of the Józef Piłsudski Institute and the Military Historical Office in Warsaw, saved in September 1939. This group includes the following teams: Adjutant Generals of the Commander-in-Chief (19181922), Silesian Uprisings, Central Lithuania (1920-1922), Archives of General Julian Stachiewicz, Archives of Edward Śmigły-Rydz, Files of General Tadeusz Rozwadowski, Archives of the Military History Office, Judicial and Honorary Affairs of Generals and Major Commanders, Ukrainian Military Mission in Poland (19191921, 1931) and partial archives of Józef Piłsudski and several smaller collections.

These files at the beginning of September 1939 were sent to Romania, where between October and February 1940, a team under the command of Major Bolesław Waligóra and Captain Stanisław Librewski re-registered the archival files. Then those acts went from Romania to France, and then to Lisbon, where in 1941 they were sent to the United States. In April 1943 the commission under the command of the Polish Ambassador in Washington, Jan Ciechanowski, opened boxes, which came from Portugal. Together with other teams, those documents were handed over to the Józef Piłsudski Institute in New York. ${ }^{63}$

In 1945 the director of the Institute, W. Jędrzejewicz wrote about a constant increase of archival sources, which were sent to the Institute. Those materials, as he stressed, came not only from the territory of the United States but also - as post

61 Report of W. Jędrzejewicz on the Second General Meeting of Members of the Institute on October 14th 1944, p. 2; Report on the activity of the Institute for the period from April 1st till June 30th 1944, pp. 3, 4; AOS in the Józef Piłsudski Institute, NY, J.Z. Dodatko's file, W. Jędrzejewicz's letter to J.Z. Dodatko, New York May 16th 1944.

62 AOS in the Józef Piłsudski Institute, NY, J.Z. Dodatko’s file, W. Jędrzejewicz's letter to J.Z. Dodatko, New York May 16th 1944.

63 Janusz Cisek, Instytut Józefa Piłsudskiego i jego zbiory, Warsaw 1997, pp. 39, 40. 
office communication improved after the end of the war - from the territory of Europe, Africa and the Middle East. Collections of private letters were especially important as they mentioned many essential political issues in their contents. The condition of the collections in libraries also increased at that time. In 1945 there were 1247 catalogued titles what constituted an increase of 480 books within a year. The prepared file counted at that time 3540 titles what constituted an increase (in comparison to the previous year) of 560 titles. A department, where periodicals were collected, also increased significantly. The Institute had already had at that time many full annual bound volumes both in the Polish language and in the English language. A particularly valuable purchase was a set of an annual bound volume of the "New York Times" collected from autumn 1941. As the director stated, the enrichment of those departments would not be possible without a large part of the gifts handed over to the Institute. In 1945, 51 people and institutions gave both very impressive collections of books and single copies. Paline C. Ramsey continued searching for materials for her bibliography of contemporary history of Poland in American libraries. W. Jędrzejewicz stated in his report that last year "showed an increase of about 560 titles of works concerning Polish history in different disciplines. Now, the bibliography contains 3540 titles and the Council of the Institute decided that progress in this field was sufficiently advanced to publish the book (in English)." Such a monograph, according to Jędrzejewicz, was supposed to be extremely valuable for all those who were involved in research in issues connected with Poland during recent years. All the more so because in order to facilitate, the works on the bibliography a two-pronged approach was adopted: by author and by subject, which enabled "finding the searched for materials faster." ${ }^{4}$

In the next report, the director of the Institute wrote that the Institute received an extremely valuable original of J. Piłsudski's letter in 1916, given by the former Minister Julisz Urlych from Cyprus, and several copies of the correspondence conducted by the Marshal, handed over by Aleksandra Piłsudska. The institution also received "interesting archives concerning the war of 1919-1920 and from the time of Polish independence that we received from Paris." These documents were handed over in deposit by the former Minister Aleksander Kawałkowski. A set of Polish maps at a scale of 1:300 000 was sent from England to the Institute by General Stachiewicz. The Institute also received new documents concerning the crime committed against Polish officers in Katyń. The institution was also donated I. Matuszewski's library and the whole political correspondence conducted by him. The Museum of the Polish Community in Chicago sent to the collections of the Institute "about 60 books and brochures of M. Siemiczkowa, and Jan Kowalski and others sent us many valuable books." This report was supplemented by a librarian of

64 Report on the activity of the Institute for the period from July 1st till September 30th 1944, p. 6; Report on the activity of the Institute for the year 1944, New York 1945, p. 30; Report of W. Jędrzejewicz for the year 1945 on the Third General Meeting of Members of the Institute, which took place on January 12th 1946, Annex no. 2, p. 1; Report on the activity of the Institute for the year 1945, New York 1946, p. 21. 
the Institute, who stated that the status of the library on January 1st 1947 amounted to 1626 catalogued works and about 80 of them were in progress. During 1946, 370 books were given to the library. The bibliography of the contemporary history of Poland, which was prepared by her, counted at that time 4258 publications, which showed an increase of 718 publications during the reporting year. In order to do this, Pauline Ramsey worked on the bibliography in the libraries of Columbia University, NY Public Library, the Library of Congress and also in the Museum of the Polish Community in Chicago. ${ }^{65}$

In 1947, the collections of the Institute were enriched with memoirs of President Raczkiewicz, which were given by his wife for safekeeping. They embraced a fouryear period from June 1940 to May 1944 and J. Piłsudski’s original letter to Kazimierz Dłuski regarding the establishing the cabinet of Ignacy Paderewski. Juliusz Łukasiewicz also placed his memoirs in 1939 (from March to November) in deposit at the Institute.

Jędrzejewicz stated also that a set consisting of press cuttings "has been definitely organised" and it counted about 6000 items and the library had 1962 titles. During 1947 there was an increase of 336 publications, all of which came from gifts, which were handed over by Jan Kowalski from New York and Ambassador Michał Sokolnicki. In 1947, the Institute received a huge set of writings concerning issues examined by the Polish government in London and documents referring to the Warsaw Uprising were also completed. The institution obtained "several first-class valuable documents concerning J. Piłsudski" and also to a large extent they were supplemented with the iconography section devoted to J. Piłsudski containing 433 pictures presenting this person. A large part of them was in an album, which was handed over to the collection of the institution. The album originally belonged to the former Prime Minister, Marian Zyndram Kościałkowski. The documentation section also greatly expanded by materials on Polish experiences in PoW camps in Germany. It was composed of materials coming from Polish liaison officers in Polish PoW camps in Germany, and huge archives of the Polish Journalists Syndicate of the former Reich. In 1948, the Journalists Syndicate in Frankfurt sent to the Institute 4 boxes and about 20 packages containing a wealth of printed matter. Jędrzejewicz stated that thanks to gifts received by the Institute "our choice has the biggest collection of Polish press printed in Germany since 1945." This team was thereby enabled to familiarise itself with all problems connected with Polish publications on the territory of Germany. Documents were supplemented thanks to numerous sets of Polish press publications, which were issued in Germany on the territories occupied by British and American people. The bibliography of sources on Polish contemporary history had at that time 4954 publications (an increase of 701 publications during a year). The whole collection had about 15000 pages. This large section, in

65 Report of the director, W. Jędrzejewicz, on the activity of the Józef Piłsudski Institute for the year 1964 on the Fourth General Meeting of Members of the Institute, on January 11th 1947, Annex no. 3, p. 2; Report on the activity of the Institute for the year 1964, New York 1946, p. 9. 
which there were brochures, was also organised. They started systematically arranging periodicals, of which "about 180 have been already classified and arranged."66

In the report for the year 1948, we can read that "about 250 books, brochures and other materials" were gathered. The donors, who handed over the biggest numbers of books at that time were: K. Bazanowski (over 1000 valuable cuttings), W. Domaniewski (about 70 books), Jan Kowalski (about 50 books), the Journalists Syndicate in Frankfurt (4 boxes and about 20 packages of printings), Michał Sokolnicki (35 books). The library of the Institute already had about 2500 books at that time, and the bibliography about 15000 pages. Both those sections were conducted voluntarily by Pauline Romsey, who was employed in the library of the Argonne Institute dealing with nuclear research in Chicago. The arrangement of the periodicals section was also done and it contained about 500 titles. It was stressed that "it is the richest section in America." Apart from gifts, which were handed over to the Institute, books and press publications were also purchased from Europe. That transpires from W. Jędrzejewicz's letter to Władysław PobógMalinowski, in which he wrote "In terms of subscriptions, we have kept up our subscription to 'Gazeta Polska' till January 1st 1949. Maybe we will stop subscribing it and the money, if there will be any, will be allotted to book purchases. I am awaiting in this respect for your suggestions, what will be better. [...] 'Polska Wierna' - there is no need to advertise it. I would like to preserve this magazine only till January 1st and then liquidate it because there is no point in paying even small sums of money. 'Gazeta Polska', which gives information on Warsaw's policy is another matter. But 'Polska Wierna' is a totally indifferent magazine for a historian. We will cancel our subscription to it on January 1 st." 67

The bulletin of 1951 contains information about gifts and deposits handed over to the archives of the Institute. The Polish Union on the territory of the American zone of Germany gave the papers of the Association of Polish Centres in Northern Bavaria, Polish Centres in Wildflaken and Ludwigsberg together with a short monograph by J. Ptakowski. Otto Szymański, who was the chairman of the Association of Polish Refugee Centres in Amberg on the territory of Germany, sent 16 packages containing the archives of this organization. Wackaw Studnicki, who came to the United States, deposited the archives that belonged to the Polish Union in Germany and materials showing the life and work of Polish refugees in these territories. Materials from Germany, had already been handed over, and constituted a supplement to those archives. The archives of H. Floyar-Rajchman were also handed over

66 Report of the director of the Institute, W. Jędrzejewicz, on the activity of the Institute on the Fifth General Meeting of Members, on January 10th 1948, Annex no. 3, p. 1; Report on the activity of the Institute for the year 1947, New York 1948, p. 6; AOS in the Józef Piłsudski Institute, NY, Kazimierz Papee's file, W. Jędrzejewicz's letter to Kazimierz Papee, New York May 28th 1948.

67 Report of the director of the Institute on the Sixth General Meeting of Members of the Institute, on January16th 1949; AOG in the Józef Piłsudski Institute, NY, W. Pobóg-Malinowski’s file, W. Jędrzejewicz's letter to W. Pobóg-Malinowski, New York June 25th 1948, zesp. 85, sygn. XLII/A/1-84, p. 333. 
to the Institute. They consisted of "thousands of letters, documents, notes, monographs, short reports, books, press publications and cuttings. The whole part of this material has already been sorted and categorized." 68

In 1951, doctor Anna Mars gave the surviving copies of appeals and leaflets from the period of the struggle for independence during 1916-1918 to the collections of the Institute. In this way, the Institute made an appeal to all, who had any materials of historical value and depositing them in the institution in New York, where "they will be carefully stored for public use. Confidential materials will be used in accordance with the will and any reservations of their donors." 69

In other reports on the activities of the Institute we can find a lot of information about archival materials gathered by different institutions, editorial sections of newspapers and weeklies and individuals handed over to the archives of the institution. An example can be an account relating to 1953, where we can find among others data on the materials donated by the Main Committee for National Treasury in London on its activities, the Main Board of the KNAPP in New York continued to regularly hand over periodicals and brochures, the League for Polish Independence acting in England and France sent sets of publications, the editorial section of "Polak w Kalifornii", acting in San Francisco, handed over a set of publications and brochures. J. Biłasiewicz from Chicago gave 350 press cuttings, the Circle of Soldiers of the Home Army in New York donated a set of their published materials, Damian Wandycz handed over his own archival collections which included among others brochures and correspondence. The Polish Library in Paris sent 9 brochures, 19 publications and memoirs, Zbigniew Spotowski from New York handed over 30 brochures, 650 Polish publications, 14 journals and 4 albums, Klaudiusz Hrabyk from New York - 48 brochures, 515 Polish publications, 8 journals, 400 press cuttings and Wacław Gawroński, Ph.D. from Toledo in Ohio - several sets of the magazine "Polityka Narodów", materials concerning Polish attitudes to J. Piłsudski, a set of Polish press cuttings in America after the death of the Marshal, an album of the Marshal's caricatures compiled by Zdzisław Czermański. The former Ambassador of the Republic of Poland in Bucharest, Leon Orłowski, gave many valuable books and brochures to the library of the Institute. ${ }^{70}$

In 1954, the Institute purchased the Walerian Płatonow Archive. This collection survived several years unrecognized in Paris with the French part of Płatonow's wife's family. After recognizing its value it was assigned for sale and shipment to the United States. The archives consisted of manuscripts, acts, publications, correspondence from the period of 1861-1863, which are a part of the legacy of the former Tsar's Minister, the Secretary of State for the Kingdom of Poland. It consisted of 43 files containing over 1300 pages, which with some exceptions concerned only

68 Bulletin of the Józef Piłsudski Institute no. 1, September 1951, p. 2.

69 Bulletin of the Józef Piłsudski Institute no. 2, March 1952, p. 2.

70 Report prepared on the Eleventh General Meeting of Members of the Institute; Announcement of the Józef Piłsudski Institute, October 1953, p. 2. 
Polish issues. Among them there is an extensive memorandum by Siergiej Szypow (in manuscript form) sent to Tsar Aleksander II concerning Russian policy towards Poland; minutes of meetings of the Agricultural Chamber in Warsaw and merchant organizations in Warsaw. Above all, there are materials concerning the January Uprising: insurgent orders, instructions of commanders, insurgent press ("Strażnica", "Ruch", "Wiadomości z placu boju"), and from the Russian side: appeals, orders of authorities, etc. Among hundreds of letters written in French, Polish and Russian there are letters written by margrave Wielopolski, count Berg, prince Gorczakow and many others. ${ }^{71}$ That same year, Stefania Bardziłowska from Boston gave collections to the Institute. Those collections concerned the social care extended to members of Polish Armed Forces. Wiesław Frontczak from Detroit donated a set of Polish press publications, which was gathered by him. J. Szlichciński sent a collection of printings and magazines from the period of the KON activity. However, financial problems of the Institute complicated the possibilities connected with gathering and organizing the collections. As it was stated in the issued announcement: "So far, archival collections [...] are stored very tightly: in three distant places: payable - an office of the Institute and a storage warehouse, and free - an underground room of a tenement building of W. Malewicz in New York." (Expenses connected with storage of the Institute's property in different places were significant. They were very rarely displayed in the financial reports, but e.g. in the report for the year 1953, the sum of 421.30 dollars is seen. ${ }^{72}$ ) Those collections, at least their most valuable part, were consolidated and located in three rooms rented by the Institute. Thanks to the efforts and work of Jan Kowalski, the secretary of the Institute, the collections were located in the Institute. The realization of this idea was partially possible because Jerzy Braynack gave the Institute a set of new metal shelves, on which both archival and library collections were arranged. Thanks to this, it was possible to start giving proper protection and access to research in the gathered materials. Therefore, "arranging and professionally inventorying the possessed and still coming collections were commenced." However, it was emphasized that the help of the Polish Community gathered in exile was indispensible to this. Apart from the financial support, which would enable renting suitable premises among others for the archives, the help of volunteers was needed to carry out works in archival materials. Jan Kowalski was a good example of such engagement, he arranged and inventoried Polish press sources coming from 41 countries. The realization of the historical and political bibliography of Poland, which was worked on in the 1940s and at the beginning of the 1950s, "was discontinued and abandoned four years ago because of the lack of funds. This bibliography is essential in the Institute for studies of the contemporary history of Poland. The resuming this essential field of

71 Minutes of the Twelfth General Meeting of Members of the Institute on April 12th 1955 in the Woodrow Wilson Foundation in New York; Announcement of the Institute, December 1955, pp. 1, 2; Report of the secretary of the Institute, Jan Kowalski, of the meeting of the Council of the Institute on June 4th 1954.

72 Report on the activity of the Institute for the year 1953 (the financial report), p. 1. 
work and making up for backwardness is an urgent necessity." ${ }^{33}$ Many people were citing a bibliographical volume published in 1952, which included in its scope the whole world for the period of 1942-1952. It was compiled and published by the Council of Foreign Affairs in New York. In connection with these assumptions, it was decided to initiate a broadly cast appeal for materials and studies produced by participants in the struggle for Polish independence during and after World War II.

\section{Publishing issues of the Institute}

In the initial version of the Statute of the Institute, which was adopted on July 4th 1943 , in point 2 , there was a regulation which reads: "Publishing books and publications devoted to these issues", that is facts associated with the contemporary history of Poland, and above all the years connected with the activity of "Józef Piłsudski and subsequent years." ${ }^{\prime 4}$ Therefore, the next day on July 5th 1943, during another meeting of the Organizing Committee of the Institute, publishing issues were discussed. During a discussion then, a decision was taken on the planned publications which were supposed to be realised by the Institute in the near future. On $\mathrm{H}$. Floyar-Rajchman's motion it was resolved that the first edition of the Constitution should be published by the National Committee of Americans of Polish Descent with which the Institute closely cooperated also in terms of publication issues. It was motivated by the urgency of this publication, which should be printed by the use of printing machines within "the next few weeks. The next editions of the Constitution (were supposed to be printed) under the aegis of the Institute."75 The issue of printing the Constitution returned again at the meeting of the Organizing Committee on December 16th 1943. While discussing the publishing section, $\mathrm{H}$. Floyar-Rajchman stated that on July 5th it was decided to publish the Constitution in two languages - Polish and English: "now only the English text is discussed. My opinion is that because the National Committee did not publish the Constitution as was possible in July, therefore, the Institute's obligation is to publish both texts. The lack of the text of the Constitution is very painful. Now we lead a struggle with it and we do not have a source. For that reason, the Institute should publish two brochures about the Constitution in two languages." In a discussion it was stated that due to the gravitas of the Institute we should not agree to publishing mass and cheap publications in it. H. Floyar-Rajchman's motion was accepted and it concerned

73 Announcement of the Józef Piłsudski Institute, July 1956, p. 2; Report of the Józef Piłsudski Institute, February 1957, p. 1.

74 Rules of the Statute of the Józef Piłsudski Institute devoted to research on contemporary history of Poland, to minutes of the organizational meeting of the Józef Piłsudski Institute in America... on August 4th 1943, Annex no. 1.

75 Rules of the Statute of the Józef Piłsudski Institute devoted to research on the contemporary history of Poland, to minutes of the organizational meeting of the Józef Piłsudski Institute in America... on August 4th 1943, Annex no. 1. Minutes of the meeting of the Organizing Committee on August 5th 1943 , p. 1. 
publishing two brochures in Polish and English "in a neat outer artwork with a circulation of 3000 copies each". Plans were also discussed connected with publishing in one volume Wybór Pism of J. Piłsudski - a choice of 83 texts which were chosen by W. Jędrzejewicz "with the authorisation of Aleksandra Piłsudska [...] the choice will include all the more important utterances of Józef Piłsudski, his letters, speeches and orders with a particular consideration of Piłsudski's attitude to America and the Polish community in America." Finally, it will consist of Piłsudski's memoirs from his clandestine work in the Polish Socialist Party, his stay in Siberia, orders of Legions' period, interviews and speeches from the period when Piłsudski was the Commander-in-Chief of the Country, and among them a historical statement on the matter of Vilnius, Lithuania and Ukraine. A lecture on the 1863 Uprising, numerous speeches on the Legions and a description of the Battle of Warsaw of August 1920 together with a map illustrating it. Piłsudski's views on issues concerning the system in Poland, his speech while placing the ashes of Juliusz Słowacki in the Wawel Castle and many others. Piłsudski's speeches devoted to the United States of America and the Polish Community as well as letters written by him to Polish organizations in America were taken into consideration intentionally. An issue concerning the number of copies was mentioned by Maksymilian Węgrzynek, who thought that the planned print run of 3000 copies is decidedly too much, because it involved increased costs of printing. Because of that he suggested to decrease the number to 1500 copies. However, at that time it was decided that because of the lack of an offer of the publishing house, an issue connected with the book layout of its outer part, its circulation and potential price were to be considered later. Ignacy Matuszewski stated that it was necessary to prepare and publish in English a collection of documents concerning Polish and Soviet relations between 1918-1941. The director of the Institute presented the issue of publishing in Polish and eventually in English the book devoted to Józef Piłsudski. Jędrzejewicz reminded that the Institute planned to publish in English a quarterly concerning "individual aspects of Polish history. It would be about the most proper publishing house." In its preliminary budgets for the period from July to December 1943 to publish Wybór Pism of J. Piłsudski 3500 dollars were assigned to publish two editions of "Materiały Historyczne" in 2000 copies - 900 dollars, on the preliminary works concerning publishing the Constitution - 200 dollars, also on the preparation of the book about Józef Piłsudski in Polish - 200 dollars. In 1944 the first report on the activity of the Institute was also published, and soon after other reports were published:

a) for the period from January 1st till March 31st 1944,

b) for the period from April 1st till June 31st 1944,

c) for the period from July 1st till September 30th 1944.

These reports were copied on a copying machine (mimeograph) and they were sent to members of the Institute. ${ }^{76}$

76 Minutes of the meeting of the Organizing Committee of the Institute... on December 16th 1943, pp. 1,2 ; ibidem, Draft of the preliminary budget of the Institute for the period from July to December, Annex 
Jędrzejewicz, in his report presented on August 30th 1944, stated that quarterly statements including the period from July 1st 1944 were issued and sent to members of the Institute. Since that time it was focused on publishing the Constitution of the Republic of Poland in Polish and it was published in a print run of 3000 copies. "About 2150 copies (together with membership copies) were sent. [...] Up to then about 85 dollars were posted to petty cash. The cost of printing amounted to 886 dollars." It was emphasized that some money was intended to go on publishing the Constitution, which was filed to print at that time, in English. About finishing the printing of the Constitution, W. Jędrzejewicz wrote with satisfaction to W. Gawroński "so I inform with pleasure [...] that it was finally printed and within a few days you will receive your copy. Copies for members of the Institute have the name of the owner printed. This is the present, which we give to our members." In another letter Jędrzejewicz wrote about the shipment to members "and then to sections and districts of the KNAPP in order to sell them. I sent 300 copies to Kogut as it embraces all branches from Detroit, Flinn, Toledo, etc. The retail price of a copy amounts to 75 cents and the Committee was given it for the retail price of 50 cents. Take care of the sales of our first publication vigorously." In the first days of August Wybór Pism of J. Piłsudski was issued in a print run of 2000 copies. The cost of printing together with the ten-percent author's fee amounted to 3270.03 dollars. At the same time, in the Institute they completed the organization of the National Committee of Americans of Polish Descent (from the Appeal to the Congress), which was issued by the KNAPP. It contained 36 documents of the most important speeches of the National Committee in 1942-1944 (appeals, resolutions, telegrams, speeches, advertisements). Hence, the work of the Institute relied on collecting the necessary material and supplying it in the footnotes, which explain under what political conditions each of the mentioned documents was created. This book was to be printed at the beginning of September under the auspices of the KNAPP. ${ }^{77}$

The rules of the Publishing Fund established from the estate of prof. Tomasz Siemiradzki were also accepted during the meeting of the Organizing Committee. It was drawn on the basis of a will, which was made on September 27th 1943 in Cleveland (Ohio) by Stanisława Siemiradzka. The most important excerpts read at that time that "to commemorate 50 years of work and effort for our Motherland, Poland in the United States of North America by the late spouse, prof. Tomasz Siemiradzki, living in Cleveland City at 1619 Clark Street, having thought over all tasks given to me during his life, now, upon our death, from his and my own will I established THE PUBLISHING FUND AT THE JÓZEF PIŁSUDSKI INSTITUTE

2; Report on the activity of the Józef Piłsudski Institute from its establishment (July 4th 1943) till December 31st 1943, p. 9; Report on the activity of the Institute for the period from 1944, New York 1945, pp. 35, 36.

77 Minutes of the meeting of the Organizing Committee of the Józef Piłsudski Institute on August 30th 1944, p. 1; AOS in the Józef Piłsudski Institute, NY, J.Z. Dodatko’s file, W. Jędrzejewicz's letter to J.Z. Dodatko, New York July 14th 1944; Report of W. Jędrzejewicz on the Second General Meeting of the Members of the Institute on October 14th 1944, Annex 2, p. 1; AOS in the Józef Piłsudski Institute, NY, Wacław Gawroński’s file, W. Jędrzejewicz’s letter to W. Gawroński, New York June 21st 1944. 
FOR RESEARCH IN THE CONTEMPORARY HISTORY OF POLAND in an amount of one thousand dollars (\$1000) for the beloved purposes as follows:

1. The money can be used on the territory of the United States solely for the purpose of writing concerning Poland's participation and martyrdom in the present war or for publishing historical works issued by the Józef Piłsudski Institute.

2. This money can be used in Poland for the purpose of the Józef Piłsudski Institute when the present war is over.

3. $1 / 5$ of the above mentioned sum (\$200) can be used for the purposes of gathering documents in the local area.

I entrust Ignacy Matuszewski, W. Jędrzejewicz, H. Rajchman, F. Januszewski and L.A. Kupferwasser with care for the Fund.

Let the Spirit of the Grand Marshal

Direct your work

In us and through us Poland lives....

(-) Stanisława Siemiradzka".

The Organizing Committee at the meeting on December 16th 1943 accepted the above regulation "The Publishing Fund after the late prof. Tomasz Siemiradzki", establishing it at the amount of 1000 dollars with the purpose of publishing some publications of the Institute. The last will of Stanisława Siemiradzka was also read out. At the same time the resignation of F. Januszewski as one the guardians of the fund was accepted. The rules of the fund were finally approved at the meeting of the Organizing Committee of the Institute on August 30th $1944 .^{78}$

In accordance with a decision approved by members of the Committee for Care, it was decided to publish Wybór Pism of Józef Piłsudski from the gathered sum in the Fund. This book was published in August 1944. In order to facilitate the sale of the book, a leaflet in Polish, which was supposed to be distributed, was added. During the preparation there was also an English version of the same leaflet, which was addressed to English libraries.

In a report filed at the Second General Meeting of Members of the Institute, the director of the Institute, W. Jędrzejewicz stated that the money of the Fund amounted to 2412.50 dollars at that time. ${ }^{79}$

At the meeting of the Council of the Institute on April 21st 1945, it was decided to supplement the composition of the Committee for Care on the Publishing Fund after prof. Tomasz Siemiradzki in order to include the following people: Janina Węgrzynek, Henryk Floyar-Rajchman, Wacław Jędrzejewicz, Kazimierz Wierzyński, L.A. Kupferwasser. ${ }^{80}$

78 Stanisława Siemiradzka, died on October 5th 1944 in Cleveland, Ohio, at the age of 77; was a perpetual member of the Józef Piłsudski Institute.

79 Report of W. Jędrzejewicz on the Second General Meeting of Members of the Institute, October 14th 1944; Report on the activity of the Józef Piłsudski Institute for the period from July 1st to September 1944, p. 5.

80 Report on the activity of the Institute for the year 1945, New York 1946, p. 17. 
According to the financial report for the period from January to November 17th 1945 the Publishing Fund amounted to 110 dollars. ${ }^{81}$

A bulletin, which was continued through the next years, was an important element in propagating the Institute and its tasks as well as the possibility to inform about actions taken by its authorities. In 1944 an extensive 68-page report (in Polish and English) appeared. In 1945 Jędrzejewicz finished and filed to print volume I (all was planned for 3 volumes) Poland in the British Parliament 1939-1945 (the book was printed by Bielawski in Trenton, in New Jersey). This work, in English, was to include Polish matters discussed in the British Parliament (the House of Commons and the House of Lords). Volume I included the period from Britain's guarantee to Poland issued on March 31st 1939 till Hitler's attack on Russia on June 22nd 1941. As the author and the director of the Institute wrote "The second revision of this large, having about 4250 pages, volume is almost finished and at the beginning of 1946 this book should come off the press." The book was published in 1946 and, as $\mathrm{W}$. Jedrzejewicz claimed in the subsequent report, met with a very favourable response from critics and prominent politicians. This proposition, according to him, was very expensive for the New York institution, which "did not benefit from any subvention was a very difficult task, which over-stretched the financial resources of the Institute." 2700 dollars were spent on Volumes I and II, which was in preparation, 3700 dollars were allotted. ${ }^{82}$ In the next report, W. Jedrzejewicz wrote that volume I was distributed in about 1700 copies. The Congress of the Polish Community in America bought 1100 copies. Books, purchased by this organization, were sent with the help of the Institute by name to addressees on all continents and in countries, where English was spoken. While establishing the addresses to which it was intended to send the book, "we received great help from the Polish Ministry of Foreign Affairs in London. Volume II is ready. Volume III - its material content was collected. ${ }^{83}$

In 1946, Michał Sokolnicki finished his first volume of journals to print. This volume included the period from 1939 to the beginning of 1942 and in connection with this the author wrote that "it is too extensive and has about 450 pages of print. I do not think that the Institute could publish it, all the more so because readers will be mainly in Europe. I would rather have the Institute as a company on my book and I thought whether it is possible to mention it as one of the publishers?" In response, Jedrzejewicz wrote that the Institute was not able at that time to publish

81 Financial report prepared for the Second General Meeting of Members of the Institute, January 12th 1946.

82 Report of W. Jędrzejewicz, the director, on the activity of the Institute on the Third General Meeting of Members of the Institute on January 12th 1946, Annex 2, p. 2; ibid., Draft of preliminary budget of incomes and expenses for the year 1946, Annex no. 5; Report of the director of the Institute on the activity of the Institute on the Fourth General Meeting of Members of the Institute January 11th 1947, Annex no. 3, p. 1; ibid., Draft of preliminary budget of incomes and expenses for the year 1947, Annex no. 6; AOS in the Józef Piłsudski Institute, NY, J.Z. Dodatko’s file, W. Jędrzejewicz’s letter to J.Z. Dodatko, New York August 28th 1945, p. 2.

83 Report of W. Jędrzejewicz on the Fifth General Meeting of Members of the Institute on January 10th 1948, Annex no. 3, p. 2. 
any greater publication because "we have difficulties in continuing our masterpiece Poland in the British Parliament although the whole material has been already gathered. However, we would eagerly serve as one of the publishers." ${ }^{84}$

Both Ignacy Matuszewski and later Wacław Jędrzejewicz maintained correspondence contact with Józef Mackiewicz, who in 1947 authorized the Institute to take care of publishing his book about Katyń (270 pages of typescript in Polish).

Jędrzejewicz wrote that "we want to publish above all in English, because we think that material in that form would fulfil its tasks to explain the secret of Katyn to the broadest masses in fascinating and accessible form - i.e. told as a story exhaustively supported by documents. In translating sample chapters I shall engage in talks with the publishers that will take place around March 20th. [...] It can be very financially profitable to the author and to the American, who would bring it here, and also to the Institute as we have such an agreement with Mackiewicz. This could mean thousands of dollars. You understand that we doubly care about publishing this book and launching it as the first history of Katyn in the world." 85

Wybór Pism, which was also published in the publishing house Gryf Printers Ltd in London, appeared under the imprimatur of the Institute in New York and in collaboration with the Józef Piłsudski Institute in London. Selected texts of Ignacy Matuszewski, published in the Polish press on the territory of the United States between October 1941 and August 1946, were placed in it. During this period, Matuszewski published 401 signed articles and journalistic items and about 130 unsigned articles, appeals, drafts of speeches, resolutions and commentaries. The selection of texts was made by a team under Kazimerz Wierzyński’s direction which comprised Irena Grabowska, Wacław Jędrzejewicz, Konrad Libicki and Damian Wandycz. Forty six texts were finally selected for publication. Those texts were also not changed in their contents but indispensable cuts were made because of their length. The book was published with the help of the Ignacy Matuszewski Publishing Fund, to which the following people belonged: Stefan Łodzieski, Eleonora Szczawińska, District no. 1 in New York and others. ${ }^{86}$

\section{The issue of purchasing a house for the Institute}

Almost from its beginning, the Institute's founders considered the need to purchase a suitable building, which would enable storing and working on its collections. The first mentions of this subject can be found in correspondence conducted in August and September 1946 between W. Jędrzejewicz and J.Z. Dodatko. A formal proposal

84 AOG in the Józef Piłsudski Institute, NY, Michał Sokolnicki, M. Sokolnicki’s letter to W. Jędrzejewicz, Ankara October 25th 1946 zesp. 91, T. (1), vol. 44-46, p. 414; ibid., W. Jędrzejewicz’s letter to M. Sokolnicki, New York December 16th 1946, zesp. 91, T. 45g.

85 AOG in the Józef Piłsudski Institute, NY, Juliusza Łukasiewicz, W. Jędrzejewicz’s letter to J. Łukasiewicz, New York March 10th 1947, vol. 14, p. 425.

86 Minutes of the General Meeting of Members of the Institute June 5th 1953, p. 2; I. Matuszewski, Wybór Pism, New York-London 1952, p. 5: Przedmowa. 
was made by members of the Polish community in Detroit who suggested the purchase of a building, in which there would be rooms both for the Institute and for the KNAPP organization with the possibility of living quarters for the directors of the institution in New York, W. Jędrzejewicz, I. Matuszewski and H. Floyar-Rajchman. ${ }^{87}$

Information concerning drafts connected with the purchase of a building can also be found in W. Jędrzejewicz's letter to the chairman of the Institute, S. Łodzieski, in which he emphasized the need to find more opportunities for the permanent existence of the Institute. Jędrzejewicz proposed to find a particular sponsor, who would accept the status of patron of this academic institution creating a foundation. Jędrzejewicz wrote: "I would see this foundation as the purchase of a house in New York that would be named after the founder [...] and where the Institute could find premises for its offices, stores for the archives and a room for meetings. The rest of the house should generate income for the activity of the Institute in the form of rent from lodgers. I think that we can purchase such a house relatively cheaply, that would be mortgaged so that the cash price would not be too high. If, apart from a room for the Institute, there could be 10 small (2-3 room) flats, the financial equation could be quite favourable in terms of servicing all liabilities (mortgage instalments, taxes, house maintenance, water charges, electricity charges, gas heating charges, fuel charges, etc. and other fixed costs) and they would give several hundred dollars of surplus for the benefit of the Institute." The contents of the letter says that the author explicitly suggested this role to Lodzieski, who having agreed to purchase the house, according to Jędrzejewicz, would crown his political and social activity for Poland on the territory of the United States. ${ }^{88}$

To sum up, the Polish independence-orientated community in the United States proved itself in difficult refugee conditions and support the activities of the Józef Piłsudski Institute in New York decade after decade. Today, after almost seventy years of existence as a well-established member of the Polish Community in America, and having countenanced the totally new political situation which came with the collapse of the Communist system in Poland, this archive and centre of learning continues to thrive.

87 AOS in the Józef Piłsudski Institute, NY, J. Z. Dodatko’s file, J.Z. Dodatko’s letter to W. Jędrzejewicz, Detroit August 24th 1946; W. Jędrzejewicz's letter to J.Z. Dodatko, New York Septemebr 5th 1946.

88 AOS in the Józef Piłsudski Institute, NY, S. Łodzieski’s file, W. Jędrzejewicz’s letter to S. Łodzieski, Wellesley Septemebr 3rd 1950. 